\title{
ĀRVALSTU PRIVĀTĀS BANKAS KĀ EIROPEIZĀCIJAS AĢENTI: LATVIJAS PIEMĒRS NO 1995. LĪDZ 2004. GADAM
}

Promocijas darba kopsavilkums politikas doktora zinātniskā grāda iegūšanai Specialitāte - starptautiskā politika 


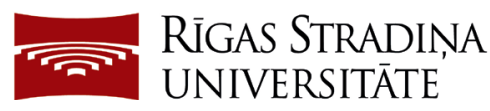

Kārlis Bukovskis

\title{
ĀRVALSTU PRIVĀTĀS BANKAS KĀ EIROPEIZĀCIJAS AG̣ENTI: LATVIJAS PIEMĒRS NO 1995. LİDZ 2004. GADAM
}

\author{
Promocijas darba kopsavilkums \\ politikas doktora zinātniskā grāda iegūšanai
}

Specialitāte - starptautiskā politika

Rīga, 2018 
Promocijas darbs izstrādāts Rīgas Stradiṇa universitātes (Latvija) Doktorantūras nodạ̦ā.

Darba zinātniskais vadītājs:

Dr. hist. Daina Bleiere,

Latvijas Universitātes Latvijas Vēstures institūta vadošā pētniece

Oficiālie recenzenti:

Dr. sc. pol. asociētais profesors Toms Rostoks,

Latvijas Universitāte

Dr. oec. profesore Inna Šteinbuka,

Latvijas Universitāte

Dr. sc. pol. profesors Ramūns Vilpišausks,

Viḷnas Universitāte (Lietuva)

Promocijas darba aizstāvēšana notiks 2019. gada 31. maijā plkst. 11.30 Rīgas Stradiṇa universitātes Politikas zinātnes promocijas padomes atklātā sēdē Rīgā, Dzirciema ielā 16, Hipokrāta auditorijā.

Ar promocijas darbu var iepazīties RSU bibliotēkā un RSU tīmekḷa vietnē: www.rsu.lv.

Promocijas padomes sekretārs:

Dr. sc. pol. docents Māris Andžāns 


\section{SATURS}

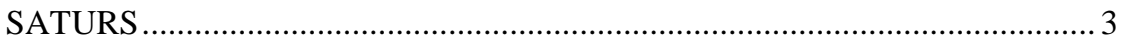

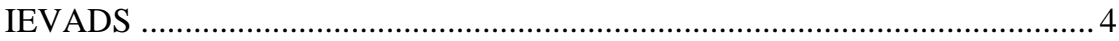

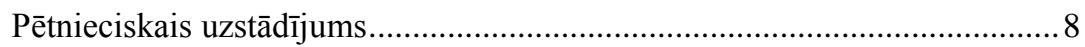

Akadēmiskais nozīmīgums un pētnieciskā novitāte..................................... 12

1. PRIVĀTIE AĢENTI EIROPEIZĀCIJAS PROCESĀ ............................... 20

2. EIROPEIZĀCIJAS AĢENTU IZPĒTES METODES................................... 24

3. PRIVĀTO ĀRVALSTU BANKU ĪSTENOTĀ LATVIJAS

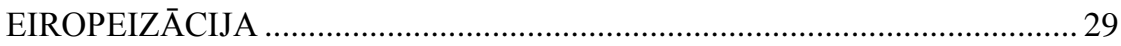

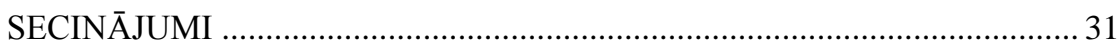

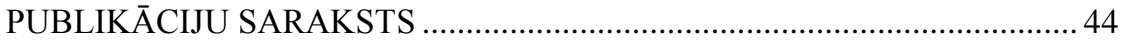

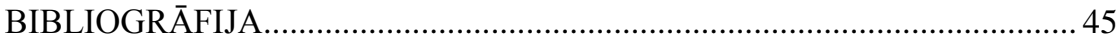




\section{IEVADS}

Eiropas Savienība (ES) ir projekts, kurā, izmantojot demokrātiskas, daudzpusējas diplomātiskās pārrunas, tiek deleǵēta suverenitāte. Starptautiskajās attiecībās tas, ka jaunas politiskās kopienas veidošana neietver vardarbību, ir unikāla sadarbības pieredze. Vienlaikus vardarbības neesamība suverenitātes mazināšanā nenozīmēe, ka neeksistē ekonomiskās un politiskās intereses, vajadzības un iemesli. Arī pats Eiropas integrācijas process un eiropeizācija neiztiek bez pragmatiskām interesēm. Tā kā normu un principu pārņemšana ir cieši saistīta ar ekonomiskiem aprēķiniem, tad šī pārņemšana nav tikai politisks process. To neapšaubāmi apzinājās arī Centrālās un Austrumeiropas valstis, kas īsi pēc Aukstā kara beigām izvēlējās virzīties uz dalību ES. Šis izvēlētais virziens uz dalību ES attiecīgajām valstīm, tostarp Latvijas Republikai, bija ne tikai sarežğīts un prasīgs process, kurā norisinājās pāreja uz demokrātisku, kapitālistisku atvērtā tirgus ekonomiku, bet arī turpmākajai ES normu pārņemšanai deviņdesmito gadu otrajā pusē bija nepieciešama piln̄̄ga administratīvo un politisko resursu mobilizācija. Gan pāreja no komunistiskās politiskās un ekonomiskās sistēmas deviņdesmito gadu pirmajā pusē, gan tai sekojošā iestāšanās ES ietvēra ne tikai juridisko un tehnisko pielāgošanos, bet arī socializāciju - Rietumu un ES normu un vērtību apgūšanu un pieņemšanu.

Šis process kopumā tiek saukts par eiropeizāciju un veido neatņemamu daļu no teorētiskās izpratnes par Eiropas integrācijas procesu un Eiropas Savienību vispār. Tā dēvētā ES "lielā sprādziena” paplašināšanās 2004. gadā eiropeizācijas teorētiķiem kopš deviņdesmito gadu vidus ir sniegusi daudz materiāla darbam. Akadēmisko pētījumu apjoma pieaugums attiecībā uz ES paplašināšanu, ES integrāciju un jo īpaši eiropeizācijas procesu bija ļoti nozīmīgs. Ģeopolitiskie un ekonomiskie apsvērumi daudzas valstis, tostarp Baltijas valstis, padarīja ļoti uzṇēmīgas pret Rietumvalstu, īpaši Eiropas Savienības, ietekmi. Dalība ES tika uzskatīta par svarīgāko mērķi un unikālu 
vēsturisko iespēju atgriezties Rietumvalstu politiskajā un ekonomiskajā telpā. Tas noteica arī ES tiesību aktu - acquis communautaire - pārņemšanu pārejas procesā esošo postkomunistisko valstu nacionālajā likumdošanā.

Šì disertācija aplūko ārvalstu privāto banku lomu laikā, kad Latvija pievienojās ES. Pētījumā tiek analizēts periods no 1995. gada, kad Baltijas valstis jeb Igaunija, Latvija un Lietuva bija atguvušas neatkarību no Padomju Savienības un veikušas pirmos liberalizācijas un privatizācijas soḷus, un, svarīgākais - iesniegušas oficiālos pieteikumus dalībai ES. 1995. gads plaši tiek uzskatīts par izšķiroši svarīgu Latvijas vēstures ǵeopolitiskās izvēles brīdi, kurā Latvija uzsāka cel̦u uz integrāciju eiroatlantiskajās ekonomiskajās un drošības struktūrās. Vienlaikus tas būtu jāuzskata arī par brīdi, kad tika pieņemts lēmums eiropeizēties. Līdz 2004. gada maijam Latvijas eiropeizācijas process bija kḷuvis visaptverošs, eiropeizācijas ağentiem atrodoties pozīcijāa, kurā tie varēja visspēcīgāk projicēt kondicionalitāti jeb izvirzìt nosacījumus, lai veicinātu pārmaiņas.

Tādējādi tas Latvijas politiskajā un ekonomiskajā vēsturē ir intriǵējošs periods, pie kura ir jāatgriežas arī vairākus gadus pēc valsts pievienošanās pārnacionālajai organizācijai, jo šajā periodā tika izveidoti š̄is Baltijas valsts idejiskie, politiskie un ekonomiskie pamati. Turklāt no ekonomikas viedokḷa pirmās ārvalstu investīcijas Latvijas banku sektorā sākās deviņdesmito gadu vidū (Barisitz, 2002), savukārt straujā Latvijas vietējo banku pārṇemšana Rietumu kapitāla rokās notika aptuveni periodā no 1998. līdz 2000. gadam. Strauji augošā pārṇemto banku kapitalizācija norisinājās pēc tam, kad Latvija bija oficiāli uzsākusi iestāšanās sarunas, un ES izcelsmes ārvalstu banku tirgus daļa visās Baltijas valstīs pakāpeniski pieauga līdz dominējošai pozīcijai jau pirms to kḷū̌sanas par ES dalībvalstīm (Swedbank, 2010; Baltic Export, 2012). Tādējādi periods no 1995. līdz 2004. gadam aizsāka attiecības starp ES valstu izcelsmes bankām un Latvijas valsti. Šīs attiecības ne tikai ḷauj izsekot līdz Latvijas 2008. 
un 2010. gada ekonomiskās krīzes saknēm, bet turpina noteikt arī Latvijas banku sistēmas struktūru.

Jēdziens "eiropeizācija" ir kḷuvis par starpdisciplināru terminu un tiek plaši izmantots akadēmiskajā literatūrā, kā arī publiskajā politiskajā diskursā un žurnālistikā. Termins tiek izmantots arī ekonomikā, politikā, kā arī tiesību jomā, lai definētu teorētisko skatījumu par Eiropas integrācijas rezultātiem un tās ietekmes veidiem. ES nav tikai pārnacionālas institūcijas, bet arī pārnacionāla tiesību sistēma, kurā ES līmeņa lēmumiem ir tieša ietekme uz valstu nacionālo līmeni. Turklāt tai ir arī socializējoša ietekme gan uz valstu lēmumu pieṇēmējiem, gan sabiedrību. Kā to ir definējuši Žaneta Ozoliṇa un Tālis Tisenkopfs: "Klasiskās integrācijas teorijas piekritēji redz ES kā valstu savstarpējās vienošanās rezultātu, kurā galvenie attiecību elementi ir valstis un ES institūcijas. Turpretim eiropeizācijas koncepta piekritēji paplašina šo attiecību bloku ar sabiedrību" (Ozoliṇa un Tisenkopfs, 2005, 31-35).

Tomēr tradicionālā eiropeizāaijas izpratne fokusējas uz publiskajām institūcijām, īpaši Eiropas Komisiju, kas virza procesu, kurā valstu publiskās institūcijas jeb pārstāvji pārṇem noteikumus un normas. Tas, kas tiek atstāts novārtā, un tiks rūpīgi analizēts šajā pētījumā, ir aspekts, ka šajā procesā cieši iesaistīti ir ar̄̄ privātie aktori. Privātos aktorus nevajadzētu uzskatīt tikai par skatītājiem vai publisko eiropeizētāju instrumentiem (skat., 1.1. tabula, Eiropeizācijas ağentu klasifikācija). Viņiem ir pašiem sava loma, jo īpaši gadījumā, ja šo privāto aktoru rīcībā ir ekonomiskie vai finanšu resursi. Tas ir, ne tikai starptautiskās organizācijas vai valstu valdības realizē socializēšanas funkcijas kā izglītotājas, standartu ieviesējas un vērtību veicinātājas, īstenojot darbakārtības noteikšanu, definējot noteikumus, veicot iestāšanās sarunas un pārņemot acquis communautaire. Publiskie un privātie aktori, īpaši ekonomiskie, piemēram, uzṇēmumi, banku grupas, daudznacionālās korporācijas viegli spēj īstenot līdzīgas funkcijas. 
Latvijas lēmumu pieņēmēju, t.i., politiskās un birokrātiskās elites, kā arī uzṇēmējdarbības pārstāvju eiropeizāciju var veicināt, sekmējot ES normu un vērtību pārṇemšanu gan tiešā veidā, gan projicējot pievilcīgu "eiropeiskā" tēlu. Eiropeizācijas mehānismi un instrumenti nav raksturīgi tikai ES institūcijām un valstu pieņemtajām normām. Privātie uzņēmumi faktiski var veikt līdzīgu funkciju. Eiropeizācijas procesu nevajadzētu pazemināt tikai līdz procesam, kurā mijiedarbojas vien̄̄gi ES institūcijas un nacionālās publiskās institūcijas. Vienlaikus šo procesu nevar uzskatīt arī par horizontālās socializācijas procesu, jo bankas var strukturāli atrasties aizdevēja un attiecīgi noteikumu definētāja pozīcijā. Turklāt eiropeizācijas process ietver ne tikai oficiālo noteikumu un institucionalizēto procedūru pārnesi un pieņemšanu, bet arī kopīgo uzskatu un normu pārņemšanu (Grabbe, 2003). Privātais aktors var funkcionēt kā aǵents, pamatojoties uz savu pārstāvju dispozīciju un projicēto paštēlu.

Šīs disertācijas motivācija ir sniegt ieguldījumu eiropeizācijas teorētiskajā konceptualizācijā. Privāto aktoru atzīšana par aktīviem eiropeizācijas procesa elementiem - ne tikai ES normu pārṇēmējiem, bet arī izmaiṇu veicinātājiem - ir būtiska, lai pilnīgāk saprastu un konceptualizētu eiropeizācijas procesu. Atbilstoši teorijai privātās politiskās struktūras, piemēram, nevalstiskās organizācijas un politiskās partijas, kā arī privātās ekonomiskās struktūras, piemēram, uzņēmumi, korporācijas, bankas utt., neatkarīgi no tā, vai tās ir pašmāju, vai ārvalstu struktūras, var tikt iekḷautas jāiekḷauj eiropeizācijas aǵentu sarakstā. Eiropeizācijas izpratnei ir nepieciešama holistiskāka pieeja, savukārt politiskā, sociālā un ekonomiskā mijiedarbība nenotiek tikai starp publiskajiem aǵentiem tiesību normu pārṇemšanas ceḷā. Eiropeizācija ir sociāli politisks process, kurā iesaistītas dažādas struktūras, fenomeni un aktori, un daļa no šiem aktoriem ir labāk piemēroti veikt eiropeizācijas aǵenta uzdevumu nekā citi. 


\section{Pētnieciskais uzstādījums}

Šajā pētījumā kā analīzes objekts ir izvēlētas ārvalstu privātās bankas. Institucionalizētas aizdošanas un aizṇemšanās nozīmes dominance ekonomikā un politiskajā izpratnē par sabiedrības un politisko pārvaldību arvien pieaug. Šī banku sektora fundamentālā daba un izšksiroši svarīgā strukturālā loma moderno kapitālistisko valstu ekonomikā un šo valstu ekonomiskajā dzīvotspējā padara bankas par acīmredzamu kandidātu kondicionalitātes spējas projicēšanai. Naudas resursa kontrole un novirzīšana ir to uzņēmējdarbības struktūru prerogatīva, kas juridiski reǵistrētas kā bankas. Visbeidzot bankas neveic tikai kapitāla iepludināšanu ekonomikā un ārvalstu tiešo investīciju piesaisti. Bankas īsteno arī socializēšanas spēju, kas tām piemīt to pārstāvju personā. Gan tiešais lobijs, ko īsteno ārvalstu bankas likumdošanas procesa gaitā, gan publiskā diskursa veidošana, izmantojot publisko analīzi un paziņojumus, gan privātā mijiedarbība starp privāto ārvalstu banku pārstāvjiem un nacionālā līmeņa lēmumu pieņēmējiem veido daļu no privātā aǵenta spējas socializêt.

Tika veikta teorētiskā un metodologiskā analīze un teorētiskie atklājumi tika testēti aplūkojot ES izcelsmes privāto ārvalstu banku lomu Latvijas eiropeizācijā. Pētījums izmantoja deduktīvo domāšanu un ar šo no augšas uz leju pieeju izvirzīja $\boldsymbol{m} \bar{e} r k ̧ i$ pierādīt, ka privātie ekonomiskie eiropeizācijas aǵenti bija spējīgi radīt leǵislatīvas un vērtību izmaiņas Latvijā. Disertācijā tika pētīta situācija akadēmiskajā literatūrā attiecībā uz privātās aǵentūras aspektu Eiropeizācijas procesā, lai definētu kritērijus, kurus jāizpilda aktoram, lai tas būtu efektīvs eiropeizācijas aǵents, un visbeidzot, vai ES izcelsmes privātās bankas izmantoja savas kapacitātes lai veicinātu Latvijas pievienošanos Eiropas Savienībai, ES normu un vērtību, sevišşki likuma varas (tiesiskuma) un labas pārvaldības principu, pārṇemšanu. 
N̦emot vērā šos apsvērumus, disertācijā tika pārbaudītas trīs hipotēzes:

1. hipotēze: Privātie aktori var būt eiropeizācijas aǵenti.

2. hipotēze: Aktoram, lai tas būtu efektīvs eiropeizācijas aǵents, ir jāpiemīt divām spējām: kondicionalitātes jeb nosacījumu izvirzī̌anas spējai un socializēšanas spējai.

3. hipotēze: ES izcelsmes privātās ārvalstu bankas izmantoja savas kondicionalitātes projicēšanas un socializēšanas spējas, lai eiropeizētu Latviju.

Lai pārbaudītu šīs trīs hipotēzes, šajā disertācijā tika izvirzīti sekojoši uzdevumi:

1) identificēt privāto aǵentu aspektu sociolog̣iskā institucionālisma pieejā un eiropeizācijas koncepta pētniecībā;

2) teorētiski izpētīt privāto eiropeizācijas aǵentu kondicionalitātes jeb nosacījumu izvirzīšanas un socializēěanas spējas un noteikt kritērijus aktoru atbilstîbai eiropeizācijas aǵenta statusam;

3) analizēt procesa izsekošanas metodes principus privāto eiropeizācijas ag̊entu izpētei;

4) izpētīit ES izcelsmes privāto ārvalstu banku izvirzītos nosacījumus laikā, kad Latvija atradās ES iestāšanās procesā un to solìto ieguvumu nozīmību;

5) izpētīt ES izcelsmes privāto ārvalstu banku draudu un solījumu ticamību un spēju pārspēt valstī esošo vietējo konkurenci, kas var kavēt eiropeizācijas procesu laikā, kad Latvija atradās ES iestāšanās procesā;

6) izpētīt Latvijas lēmumu pieṇēmēju un ES izcelsmes privāto ārvalstu banku intensīvo mijiedarbību un banku pielietotās Latvijas lēmumu pieñēmēju socializēšanas stratēgijas; 
7) izpētīt, vai ES izcelsmes privātās ārvalstu bankas pašas sekoja saviem sludinātajiem principiem, Latvijas iestāšanās Eiropas Savienībā laikā un vai standarti atbilda Latvijas lēmumu pieņēmēju izpratnei.

No metodologiskās perspektīvas, šis pētījums pievērsās procesa izsekošanai (process tracing) kā piemērotākajai pieejai, lai identificētu cēloṇsakarību starp ārvalstu privāto banku lomu un rīcību un Latvijas eiropeizāciju, t.i., ES tiesību normu, vērtību un principu pārņemšanu, ir procesa izsekošanas metode. Procesa izsekošana ir noderīga metode pētījumā, kas, balstoties uz socioloǵiskā institucionālisma teoriju, sintezē kognitīvisma un racionālisma aspektus. Pamatojoties uz deduktīvās logiikas teoriju, pārvaldīta procesa izsekošana atbilst šīs disertācijas mērķiem teorijas empīriskās pārbaudes kontekstā. Tas ir, eiropeizācijas aǵentu noteikšanas kritēriju teorētiskais modelis, kas izstrādāts disertācijas pirmajā nodaḷā, tiek empīriski pārbaudīts, analizējot konkrēto Latvijas eiropeizācijas gadījumu. Šī analīze tiek veikta, pamatojoties uz epistemologiskā racionālisma nostāju, jo šī pētījuma ietvaros tiek uzskatīts, ka eiropeizācijas process ir novērojams un aǵentu loma - pārbaudāma. Kaut arī no epistemoloǵijas viedokḷa procesa izsekošanas metode ietilpst pozitīvistu (racionālistu) pieejā, tas nenozīmē, ka nav iespējams savienot racionālistu un sociālo ontologiju, lai tādējādi palielinātu skaidrojuma vērtību un ietvertu gan materiālo, gan normatīvo vērtību analīzi.

Procesa izsekošanas izpētes metode, kas tiek izmantots šajā pētījumā, ir balstīta uz to, lai izpētītu, vai seši eiropeizācijas aǵenta noteikšanai izvirzītie kritēriji veido cēloṇsakarību starp ES izcelsmes privāto banku darbībām un Latvijas eiropeizāciju (skat., 2.1. tabula, Pētījuma shēma). Kritēriji veica ne tikai iedarbības mehānismu funkciju, bet, sniedzot atbildi uz jautājumu, vai bankas Latvijas eiropeizācijai izmantoja savas kondicionalitātes un socializēšanas spējas un vai privātie ekonomiskie eiropeizācijas aǵenti ir nozīmīgs faktors ne tikai 
teorētiski, bet arī empīriski, l̦auj arī izdarīt secinājumus par Zviedrijas, Somijas un Vācijas banku lomu Latvijas eiropeizācijā.

Kā detalizēti skaidrots šīs disertācijas otrajā nodaḷā, procesa izsekošanas metodes izstrāde un piemērošana Latvijas gadījuma analīzei, ir optimāla pieeja, jo par attiecīgo tēmu ir pieejams salīdzinoši neliels empīrisko materiālu un datu daudzums. Publiski pieejamo materiālu skaits attiecībā uz privātajām ārvalstu bankām un to formālo un neformālo mijiedarbību ar nacionālajiem lēmumu pieņēmējiem, ir ierobežots. Izņemot ekonomiskos datus, kas tika izmantoti, lai pamatotu argumentāciju un apliecinātu korelāciju, reti publicētos paziņojumus plašsaziņas līdzekḷos, kā arī publiski pieejamos pārskatus, šajā pētījumā analizētā procesa izpētei nepieciešamie dati lielākoties bija jāiegūst no 25 daļēji strukturētām dziļajām intervijām gan ar attiecīgo banku, gan valsts nacionālā līmeņa lēmumu pieņēmējiem. Papildus tika veiktas arī 4 ekspertu intervijas.

Analīzē izmantotie dokumenti un datu avoti sastāvēja no attiecīgajiem iekšējās un ārējās korespondences materiāliem par ES integrācijas jautājumiem, kas pieejami Finanšu ministrijas arhīvā, Latvijas Bankas un attiecīgo pētījumā iekḷauto banku ikgadējiem publiskajiem pārskatiem, Finanšu un kapitāla tirgus komisijas, Ārvalstu investoru padomes Latvijā un Latvijas Komercbanku asociācijas ziṇojumiem un pārskatiem, kā arī plašsaziņas līdzekḷu publikācijām, kas pieejamas laikrakstu un LETA arhīvos. Šie materiāli tika izmantoti, lai izsekotu attiecīgo ārvalstu banku klātbūtnei, lomai, darbībām un ietekmei, Latvijai atrodoties iestāšanās Eiropas Savienībā procesā, kas risinājās periodā no 1995. līdz 2004. gadam.

Promocijas darbs sastāv no trim nodaḷām: 1) Privātie aǵenti eiropeizācijas procesā, kurā tiek aplūkoti teorētiskie aspekti; 2) Eiropeizācijas aǵentu izpētes metodes, kurā aplūkota metodologiskā argumentācija; un 3) Privāto ārvalstu banku īstenotā Latvijas eiropeizācija, kurā tika veikta Latvijas piemēra empīiskāa 
analīze. Visas trīs sastāv no vairākām apakšnodaḷām, kas detalizēti izklāstītas to attiecīgajās nodaļās turpmākā tekstā.

\section{Akadēmiskais noz̄imīgums un pētnieciskā novitāte}

Eiropas Savienības paplašināšanās ir bijusi un joprojām būs aktuāla izpētes un teorētiskās modelēšanas tēma (Schimmelfennig and Sedelmeier, 2005a), jo jaunu dalībvalstu iekḷaušanas iespējamība joprojām ir augsta. Šajā promocijas darbā tika analizēta ES paplašināšanās aspekts un situācija konkrētajā valstī. Eiropeizācijas process, tika aplūkots no sociologiskā institucionālisma (konstruktīvisma institucionālisma) viedokḷa, izvirzot sešus konceptuālos kritērijus, lai analizētu potenciālos eiropeizācijas aǵentus. Tad šis pētījums, izmantojot procesa izsekošanas metodi, aplūkoja ES izcelsmes ārvalstu privāto banku lomu un ietekmi uz Latvijas iestāšanās procesu ES un valsts eiropeizāciju. Šì pētījuma akadēmiskais pienākums bija pievērsties neatbildētajam jautājumam par privāto ekonomisko aktoru potenciālu funkcionēt kā eiropeizācijas aǵentiem un veicināt politiskās un tiesiskās izmaiņas mērķa valstīs. Attiecīgi, ka privātie ārvalstu politiskie un ekonomiskie aktori var būt eiropeizācijas aǵenti - aktīvi par daḷu no eiropeizācijas procesa uzskatīto standartu, normu un principu veicinātāji.

Šis pētījums atšķiras no agrākiem pētījumiem, jo tā fokuss ir uz privātajiem ekonomiskajiem aktoriem kā izmaiņu veicinātājiem eiropeizācijas mērķa valstī, t.i., eiropeizācijas aǵentiem. Tas ne tikai balstās uz socioloǵiskā institucionālisma teorētisko pieeju attiecībā uz eiropeizācijas procesa skaidrojumu, bet paplašina arī eiropeizācijas jēezienu, to iekḷaujot starptautiskās politiskās ekonomikas disciplīnā. Lai pilnībā izmantotu sociologiiskā institucionālisma "racionālo pusi", ir l̦oti svarīgi ņemt vērā arī ekonomiskos argumentus. Eiropeizācijas jēdziens un sociologiiskais 
institucionālisms l̦auj pievērsties tā dēvētajiem "ja" un "kā" jautājumiem, tikai dalı̄èji sniedzot atbildes uz jautājumu "kāpēc". Savukārt starptautiskās politiskās ekonomikas argumenti ļauj skaidrot "kāpēc" aspektu. Šì pētījuma kontekstā tie l̦auj atbildēt uz jautājumiem - kāpēc ārvalstu privātās bankas rīkojas kā eiropeizācijas aǵenti un kāpēc eiropeizācijas mērķa valsts nacionālā līmeņa lēmumu pieņēmēji ir gatavi izpildīt prasības un ievērot nosacījumus.

Zināmā mērā līdzịgu sociolog̣iskā institucionālisma un politiskās ekonomikas aspektu savienojumu iepriekš ir veidojusi Reičela Epsteina (Rachel Epstein) attiecībā uz postkomunistiskās Eiropas banku sektora internacionalizāciju. Autore izvirzīja institūciju starptautiskās ietekmes teoriju, apgalvojot, ka “(..) lai ārējie ieteikumi vai nosacījumu izvirzīšana radītu plānoto rezultātu, tie ir jāpiedāvā noteiktā sociālajā kontekstā” (Epstein, 2008, 883). Tomēr R. Epsteinas trīs izstrādātās sociālā konteksta pazīmes, kas ietekmē varas vai nosacījumu izvirzī̌sanas uztveri, ir nepietiekamas, lai pilnībā izskaidrotu mijiedarbību starp finanšu sektora ārvalstu aktoriem un nacionālā līmeņa lēmumu pieñēmējiem. Tāpēc, lai definētu sešus eiropeizācijas aǵenta noteikšanas kritērijus (skat., 1.1. attēls, Eiropeizācijas aǵentu kapacitātes), disertācijā izmantoti arī citu socioloǵiskā institucionālisma "starptautiskā spārna" pārstāvju darbi.

Galvenais iedvesmas avots racionālisma argumentu jeb racionālisma kritēriju izmantošanai šajā pētījumā izstrādātajā konceptuālajā modelī ir Franka Šimelfeniga (Frank Schimmelfennig) darbā (2000), kā arī viņa un Ulriha Zēdelmaijera (Ulrich Sedelmeier) rakstītais par 2004. gada ES paplašināšanās kārtā uzṇemto valstu eiropeizāciju (2004, 2005). Šo abu eiropeizācijas teorētiķu uzstādījumi sniedz vērtīgu ieskatu pazīmēs un īpašībās, kas bija ļoti svarīgas attiecībā uz ES projicēto kondicionalitāti periodā, kad tika veiktas iestāšanās sarunas ar Centrāleiropas un Austrumeiropas valstīm. Viņu izmantotā pieeja l̦auj izprast specifiskos priekšnoteikumus, lai normu un principu pārņemšana notiktu 
efektīvi. Starp svarīgākajiem teorētiskajiem materiāliem, kas tiek izmantots kritēriju definēšanai, ir arī Heteres Grābes (Heather Grabbe) $(2001,2003,2005)$ rakstītais par Centrāleiropas un Austrumeiropas valstu eiropeizāciju, izmantojot kondicionalitāti (noteikumu izvirzī̌sanu). Viņas pētījums l̦auj konceptualizēt ES noteikumu izvirzīšanu un iegūt spēcīgus teorētiskos argumentus šajā pētījumā izstrādāto racionālās izvēles kritēriju atbalstam.

Piektais un sestais kritērijs ir izstrādāti, pamatojoties uz pētījumu par Eiropas valstu starptautisko socializēšanu, ko sarakstījis F. Šimelfenigs un kuras līdzautori ir Stefans Engerts (Stefan Engert) un Heiki Knobels (Heiki Knobel) (2006). Autori uz ES institūciju politiskās kondicionalitātes un socializēšanas varu raugās no strukturālisma viedokḷa, kas l̦auj definēt teorētiskos argumentus attiecībā uz eiropeizācijas aǵentu socializēšanas stratēǵijām un spējām. Visbeidzot vēl viens nozīmīgs teorētiskās ietekmes avots ir Džefrija Čekela (Jeffrey T. Checkel) (1999, 2001, 2005, Zürn and Checkel, 2005) rakstītais par argumentētās pārliecināšanas un socializēšanas mehānismiem, kas palīdz pamatot un definēt starptautiskās socializēšanas argumentus no mērķa valsts lēmumu pieñēmēju sociālās un psihologiskās ietekmēšanas vektoru un taktikas veidu skatupunkta.

Jāpiemin, ka ekonomisko aktoru kā politisko aǵentu, t.i., ārvalstu privāto banku kā Latvijas Republikas eiropeizētāju analīze ir veikta saskaņā ar Sjūzenas Streindžas (Susan Strange) (1996, 1998a, 1998b) starptautiskās politiskās ekonomikas argumentiem par finanšu tirgu un finanšu aktoru lomu, kā arī politisko un ekonomisko ietekmi attiecībā uz modernajām valstīm. Papildus teorētiskā materiāla izpētei tika veikta arī izsmel̦oša akadēmisko publikāciju par eiropeizācijas procesu un jēdzienu analīze, īpaši pievēršoties Roberta Lādreha (Robert Ladrech) (1994, 2009, 2010), Taņas A. Bērcelas (Tanja A. Börzel) (1999, 2003, 2011), Bērcelas un Tomasa Rises (Thomas Risse) (2000, 2003, 2009), Rises (2009), kā arī Rises, Marijas Grīnas Koulesas (Maria Green 
Cowles) un Džeimsa A. Kaporaso (James A. Caporaso) (2001) un Kristofa Knila (Christoph Knill) (2001) un Knila un Dirka Lemkūla (Dirk Lehmkuhl) (1999) rakstītajam par eiropeizācijas konceptuālajām paz̄mēm, tās vektoriem, mehānismiem un jaunā institucionālisma metodologisko pieeju šim fenomenam.

Šis pētījums izdalās no esošās akadēmiskās literatūras tieši socioloǵiskā institucionālisma jomā. Skatījums uz privātajiem aktoriem kā eiropeizācijas veicinātājiem, sekmētājiem (aǵentiem) ir visbūtiskākais jauninājums eiropeizācijas jēedziena un eiropeizācijas procesa izpētē. Turklāt pētījums sniedz arī jaunu konceptuālo modeli eiropeizācijas aǵentu analīzei. Tajā tiek definēti seši kritēriji, kas aktoru padara par eiropeizācijas aǵentu. Socioloǵiskajā institucionālismā un eiropeizācijas izpētē "aǵentu aspekts ir pašsaprotams, jo ES institūcijas ievieš noteikumus, un attiecīgi tas netiek atsevišķi izdalīts" (Schimmelfennig, 2018). Noteikumu pārnese ir eiropeizācijas procesa analīzes centrālais objekts. Un gandrīz bez izṇēmumiem attiecīgā izpēte ir bijusi veltīta publiskajiem eiropeizācijas ag̊entiem, t. i., Eiropas Komisijai, Eiropas Savienības Tiesai vai ES dalībvalstu politiķiem un birokrātiem.

Privāto aktoru kā eiropeizācijas aǵentu aspekts ir bijis nepietiekami analizēts. Viens no retajiem gadījumiem, kad akadēmiskajā literatūrā tiek minēts šis aspekts, ir, piemēram, kad Hetere Grābe savā vispusīgajā pētījumā "ES pārveidojošā vara" (The EU's Transformative Power) atsaucas uz privātā sektora aktoriem saistībā ar ES stingro un maigo politikas pārṇemšanas veidu Centrāleiropā un Austrumeiropā, norādot, ka "CAE valstu privātais sektors pārṇēma ES praksi to iekšèjā tirgū pastāvošās konkurences (efektivitātes ieguvumi, tehnologiiju pārnese) vai ES tirgos pastāvošās konkurences (produktu un procesu standarti) dēḷ” (Grabbe, 2005, 58-59, 3.1. tabula). Autore nepārprotami norāda, ka privātie ekonomiskie aktori gūst papildu priekšrocības no ES normu pārṇemšanas valsts iekšienē, bet viņa uz tiem neraugās kā šo standartu un principu ieviešanas veicinātājiem. Turklāt attiecībā uz politisko 
ietekmi H. Grābe norāda, ka "ārvalstu tiešo investīciju izpēte vedina uz domu par "mācību procesu", bet tas ir l̦oti grūti izmērāms (...), [jo] ietekme ir atkarīga no sektora un konkurences veida un intensitātes” (Grabbe, 2005, 59). Šì pieņēmuma kontekstā disertācijā ir veikta ārvalstu kapitāla investoru lomas analīze, lai pierādītu to kā eiropeizācijas aǵentu lomu un ietekmi. Privāto aktoru kā eiropeizācijas aǵentu aspekta izpēte ir tikusi skarta Aleksa Vorlija (Alex Warleigh) rakstā par vietējām nevalstiskajām organizācijām kā pilsoniskās sabiedrības eiropeizācijas aǵentiem. Autors savā rakstā secināja, ka resursu trūkuma, elitārās iekšêjās vadības un tā fakta, ka “(..) NVO atbalstītāji patiesībā nevēlas uzṇemties šādu lomu" (Warleigh, 2010, 635), dēḷ, NVO nedarbojas kā spējīgi pilsoniskās sabiedrības eiropeizētāji.

Papildus tam, ka šis ir pirmais pētījums, kurā analizēts privāto ekonomisko aktoru kā eiropeizācijas aǵentu aspekts, un tikai otrais pēc Epsteinas (2008), kurā tiek pētīta mijiedarbība starp eiropeizācijas procesu un CAE valstu finanšu sektoru internacionalizāciju un attiecīgi privātajiem eiropeizācijas aǵentiem, šim pētījumam piemīt arī empīriska novitāte. Tas pievieno jaunu skatījumu uz Latvijas iestāšanās procesu Eiropas Savienībā un tās eiropeizāciju no Latvijas lēmumu pieņēmēju, politiķu un institūciju skatupunkta, kā arī analizē ES izcelsmes ārvalstu privāto banku lomu Latvijā pirms tās iestāšanās ES. Pētījums papildina arī praktiskās politikas un teorētisko pētījumu klāstu, starp kuriem kā svarīgākie minami: vispusīgais pārskats Žanetas Ozoliṇas un Tāḷa Tisenkopfa (2005) vadībā sagatavotajā publikācijā "Latvija eiropeizācijas krustcel̦os”, Providus pētnieku izstrādātais pētījums pirms (Svendsen, 2004) un īsi pēc Latvijas iestāšanas ES (Akule, 2007), kā arī pētījumi, kuros iekḷautas nodaļas jeb Latvijas gadījuma analīze saistībā ar tādām tēmām kā Baltijas valstu pilsonisko sabiedrību eiropeizācija (Spurga, 2007), CAE valstu politisko partiju eiropeizācija (Walecki, 2007), jauno ES dalībvalstu ekonomiskās politikas eiropeizācija (Kostadinova, 2007), minoritāšu aizsardzības politiku eiropeizācija 
(Tugdar, 2014), Latvijas pētniecības politika (Tõnismann and Muizniece, 2016), ārvalstu palīdzības eiropeizācija (Timofejevs Henriksson, 2014), seksuālo minoritāšu tiesību eiropeizācija (Pelz, 2016) un svarīgākais - etniskās politikas izmainas Centrāleiropas un Austrumeiropas valstīs (Kelley, 2006). Promocijas darba ieguldījums esošajā akadēmiskajā literatūrā ir padziļinātā Latvijas lēmumu pieņēmēju un finanšu sektora eiropeizācijas analīze. Vienlaikus būtu jāpiemin, ka ir pieejams ievērojams pētījumu klāsts par vispārējo Igaunijas, Latvijas un Lietuvas integrācijas procesu Eiropas Savienībā atsevišksi vai kopā, kā daži no svarīgākajiem jānorāda šie: "Eiropas Savienība un Baltijas valstis: pārvald̄̄bas veidu izmainas" (The European Union and the Baltic States: Changing Forms of Governance) (Jacobsson, 2010a), Petera van Elsvēga (Peter Van Elsuwege) (2008) vispusīgā analīze par Baltijas valstu iestāšanos vai arī Vello Petai (Vello Pettai) un Jana Zel̦onkas (Jan Zielonka) (2003) vadībā sagatavotā grāmata par monumentālajām izmaiņām, pārejot no postkomunisma uz ES paplašināšanos, vai arī Viljara Vēbela (Viljar Veebel) (2012) raksti par ES pozit̄̄vo kondicionalitāti Baltijas valstīs. Tomēr nevienā no šiem darbiem nav sniegta banku sektora lomas empīriskā analīze.

Latvijas banku sektora stāvoklim iestāšanās Eiropas Savienībā kontekstā ir veltìta gan akadēmiskās, gan pētnieciskās jomas uzmanība, bet gandrīz bez izṇēmumiem tikai ekonomikas vai ekonomikas vēstures disciplīnās. Nozīmīgākie darbi, kuros cita starpā vai ekskluzīvi Latvijas iestāšanās ES izpētei pievērsušies autori Latvijā, ir Jura Vīksniņa un Innas Šteinbukas rediǵētais rakstu krājums "Latvija cẹ̦ā uz XXI gadsimtu" (Latvia Entering the XXIst Century) (2000), jaunākais vispusīgais izdevums Gata Krūmiņa vadībā par Latvijas tautsaimniecības vēsturi (2017) un pētījums par Eiropas Savienības ekonomiskās politikas ietekmi uz Latviju (Dovladbekova, Eteris and Zelmenis, 2008). Visi šie materiāli kopā ar Martina Adāla (Martin Adahl) analīzi (2002) kḷuva arī par šīs disertācijas svarīgākajiem datu un konceptualizāciju avotiem. Būtu jāpiemin arī, 
ka pētījumi par Baltijas valstu finanšu un ekonomisko attīstību iestāšanās ES kontekstā ir pieejami arī Latvijas Bankas, Starptautiskā Valūtas fonda un Pasaules Bankas pārskatos, tostarp par postpadomju valstu tirdzniecības globalizāciju un Baltijas panākumiem diversifikācijā (Broadman, 2005) vai vispārīgo postpadomju valstu ekonomisko atkopšanos (Kolodko, 2000). Pretēji ekonomikas disciplīnā veiktajai pētniecībai promocijas darbā bankas un finanšu sektors tiek aplūkots no starptautiskās politiskās ekonomikas un eiropeizācijas perspektīvas. Atšksirīibā no ekonomikā veiktajiem pētījumiem, šī disertācija nodarbojas ar bankām un finanšu sektoru no starptautiskās politiskās ekonomikas un eiropeizācijas perspektīvas, bet vienlaicīgi atšķiras no Denisa Kvinna (Dennis P. Quinn) un Karlas Inklanas (Carla Inclan) raksta (1997) par politiskiem motīviem valsts atvēršanai ārvalstu finanšu kapitālam, jo tas neietver eiropeizācijas aspektu.

Tādējādi no teorētiskā viedokḷa šis pētījums paplašina eiropeizācijas jēdziena piemērošanu, iekl̦aujot to arī starptautisko attiecību un starptautiskās politiskās ekonomikas disciplīnās, kā arī sniedz papildu teorētisko argumentāciju un konceptuālo modeli, ko varētu turpmāk piemērot citu valstu un to eiropeiskās integrācijas pieredzes analīzē. N, Nemot vērā, ka iepriekš nav ticis veikts neviens vispusīgs sociālo zinātņu pētījums par ārvalstu banku politisko lomu kādā no trim Baltijas valstīm, šī analīze papildina nelielo pētījumu apjomu konkrēti par Latviju un sniedz jaunus empīriskos materiālus gan par Latvijas ekonomisko, gan politisko integrāciju Eiropas Savienībā.

Šì disertācija ir arī praktiska nozīme mūsdienu skatījumāa. Latvijas pieredze joprojām piedāvā mācības citām valstīm, kuras tiecas uz dalību ES. Latvijas pirmspievienošanās situācija nebija unikāla, un privāto ekonomisko dalībnieku nozīmes izpratne un iesaistǐšanās ar tām ir būtiska pašreizējām un potenciālajām kandidātvalstīm. Kamēr Eiropas Savienības paplašināšanās nav beigusies un ir vēl valstis, kas vēlas pievienoties organizācijai un uzsākt 
eiropeizācijas procesu, Latvijas pieredze ir noderīga. Šajā situācijā šī disertācija l̦aus saprast praktiskos aspektus, kas saistīti ar ārvalstu privāto ekonomisko aǵentu iesaistīšanos, pievienoto vērtību sadarbībai ar viniiem un savstarpējās mijiedarbības cel̦iem.

Visbeidzot, šīs disertācijas rezultāti ir tikuši prezentēti trijās starptautiskajās zinātniskajās konferencēs:

1) 2017. gada 23. novembrī starptautiskajā konferencē 1st Riga Readings in Social Sciences (RRSS) par tēmu "Pilsoniskā sabiedrība, nevienlīdzība un izmaiņas pēc krīzes" (Civic society, inequality and post-crisis transformations) Rīgā, Latvijā;

2) 2017. gada 27.-29. novembrī MIRDEC sestajā starptautiskajā sociālo zinātņu akadēmiskajā konferencē (MIRDEC-6th International Academic Conference on Social Sciences) Lisabonā, Portugālē; un

3) 2018. gada 12.-13. jūlijā UACES Absolventu foruma 2018. gada konferencē (UACES Graduate Forum Conference 2018) Katoḷu universitātē Lēvenā, Beḷgijāa

Šīs disertācijas pētnieciskie rezultāti ir tikuši publicēti akadēmiskajos izdevumos latviešu valodā: 1) Bukovskis, K. 2018. Ziemel̦valstu privāto banku ietekme uz Latvijas iestāšanās Eiropas Savienībā procesu no 1995. līdz 2004. gadam. Zinātniskie raksti: 2017. gada sociālo zinātņu nozares pētnieciskā darba publikācijas. Politika un tiesības. Rīga: Rīgas Stradiṇa universitāte, 53-60; un 2) Bukovskis, K. 2017. Privātie ağenti eiropeizācijas procesā. Zinātniskie raksti: 2016. gada sociālo zinātņu nozares pētnieciskā darba publikācijas: Politika. Rīga: Rīgas Stradiṇa universitāte, 45-56. 


\section{PRIVĀTIE AĢENTI EIROPEIZĀCIJAS PROCESĀ}

Tradicionāli eiropeizācijas jēdziens tiek ekskluzīvi attiecināts uz procesiem, kas aptver tiešu mijiedarbību ar ES institūcijām un tiesību sistēmu. No šīs pieejas izriet galvenā problēma, kas nel̦auj veikt pilnīgāku eiropeizācijas fenomena analīzi, proti, akadēmiskajā literatūrā eiropeizācija tradicionāli tiek saprasta un analizēta no ES un nacionālo valstu, to publisko institūciju vai iedzīvotāju mijiedarbības skatupunkta. Kā skaidro Taņa A. Bērcela un Diāna Panke (Diana Panke): "Viens eiropeizācijas izpētes virziens analizē to, kā dalībvalstis veido ES politiskās programmas, politiku un sabiedrisko iekārtu, savukārt otrs fokusējas uz to, kā ES izraisa valstu iekšējās pārmaiṇas” (Börzel and Panke, 2013, 116). Šis process iekḷauj divus aktoru tipus: publiskos un privātos, katrs no kuriem var tik tālāk sadalīts attiecīgi ekonomiskajos un politiskajos aǵentos (skat., 1.1. tabulu).

1.1. tabula

\section{Eiropeizācijas aǵentu klasifikācija}

\begin{tabular}{|c|c|c|c|}
\hline \multicolumn{4}{|c|}{ Eiropeizācijas aǵenti } \\
\hline \multicolumn{2}{|c|}{ Publiskie } & \multicolumn{2}{|c|}{ Privātie } \\
\hline $\begin{array}{c}\text { Politiskie (Eiropas } \\
\text { Komisija, } \\
\text { Dalībvalstis, } \\
\text { Eiropas } \\
\text { Parlaments u.c.) }\end{array}$ & $\begin{array}{c}\text { Ekonomiskie } \\
\text { (Eiropas Centrālā } \\
\text { banka, Eiropas } \\
\text { Investīciju banka } \\
\text { u.c.) }\end{array}$ & $\begin{array}{c}\text { Politiskie (ES } \\
\text { atbalstošās } \\
\text { nevalstiskās } \\
\text { organizācijas, } \\
\text { individuālie lobisti, } \\
\text { pan-Eiropas } \\
\text { pilsoniskā } \\
\text { sabiedrība) }\end{array}$ & $\begin{array}{l}\text { Ekonomiskie } \\
\text { (uzñēmumi, } \\
\text { individuālie } \\
\text { komersanti, } \\
\text { privātās banka) }\end{array}$ \\
\hline
\end{tabular}

Akadēmiskajā literatūrā privāto aktoru eiropeizācija un to loma citu aktoru eiropeizācijā gandrīz bez izṇēmumiem tiek skatīta tikai politisko partiju analīzes griezumā, lai gan pieminams ir arī Aleksa Vorlija (2001) skatījums uz nevalstiskajām organizācijām kā valsts pilsoniskās sabiedrības eiropeizācijas 
aǵentiem. Ekonomiskie aktori un ekonomiskie sektori literatūrā tiek analizēti vien̄̄gi kā eiropeizācijas mērksi, kā vienības, kas tiek eiropeizētas. Privātie politiskie un ekonomiskie aktori nav publiskie aktori, t.i. valsts vai Eiropas Savienības institūcijas, kurām piemīt spēja uzspiest saistošas prasības par specifisku principu ieviešanu vai rīcību no nāciju valstu vai organizāciju puses. Ir pieņemts, ka privātie aktori nevar izdarīt identisku juridisko spiedienu, kāds piemīt starptautiskajām publiskajām institūcijām un nacionālo valstu institūcijām. Bet, ja eiropeizācijas process tiek saprasts tikai kā tieša mijiedarbība starp Eiropas Savienības iestādēm un partneriem, novārtā tiek atstāts tas, ka privātie dalībnieki, jo īpaši uzņēmumi, var būt arī eiropeizācijas veicinātāji. Tādējādi šajā nodaļā veiktajā teorētiskajā diskusijāa, tiek noteikti un nodalīti eiropeizācijas procesa aǵenti, kā arī tiek izvirzītas prasības, lai aktors būtu uzskatāms par aǵentu.

Eiropeizācijas process nav tikai institucionāli tiesiska normu pārņemšana. Tas ir arī socializācijas process un process, kas rada Eiropas Savienības dalībvalstu un kandidātvalstu iekšèjās izmainas. Promocijas darbā galvenais analītiskais uzsvars tiek likts uz aǵentu aspektu, t. i., vai aǵenti var veicināt un īstenot tādu pašu ietekmi uz mērķa valsts nacionālo lēmumu pieņēmējiem kā publiskie eiropeizācijas aǵenti. Šajā nodạ̧ā tika analizēta iespēja attiecināt eiropeizācijas procesu un eiropeizācijas aǵentu funkcijas uz privātajiem politiskajiem un ekonomiskajiem aktoriem.

Šīs nodaļas pirmo divu daļu (Teorētiskās un metodoloǵiskās pieejas eiropeizācijai; un Eiropeizācijas definīcijas un vektori) mērķis bija pievērsties šīs disertācijas pirmajai hipotēzei, t. i., atbildēt uz jautājumu, vai privātie aktori var būt eiropeizācijas aǵenti. Savukārt šīs nodaļas trešajā daļāa (Privāto eiropeizācijas aǵentu nosacījumu izvirzīšanas un socializācijas spējas) tika pārbaudīta otrā hipotēze, t. i., sniegta atbilde uz jautājumu, vai privātajiem ekonomiskajiem aktoriem teorētiski piemīt kondicionalitātes un socializēšanas spējas, kas 
nepieciešamas, lai tie funkcionētu kā eiropeizācijas aǵenti. Nodaļas sākumā tiek veikta eiropeizācijas jēdzienu un galvenajām teorētiskajām un metodoloǵiskajām pieejām analīze, kas tiek izmantotas šī procesa skaidrošanai. Tiek analizētas eiropeizācijas definīcijas un vektori privāto aǵentu aspekta kontekstā. Nodaļas noslēgumā tiek aplūkots socioloǵiskais institucionālisms kā teorētiskais pamatojums, īpaši pievēršoties kondicionalitātes un stratēǵiskās socializēšanas aspektiem un definējot sešus Eiropeizācijas aǵenta kritērijus.

Disertācijā tika teorētiski secināts, ka ar ekonomiskajiem un/vai finanšu resursiem apveltītie aktori var projicēt kondicionalitāti un veikt nacionālā līmeņa lēmumpieņēmēju socializēšanu mērķa valstī. Ārvalstu uzņēmumu intereses ir ne tikai ekonomiskas, bet arī politiskas. Tas ir, tādi privātie ekonomiskie aktori kā kompānijas, korporācijas, individuālie uzṇēmumi un bankas ir ieinteresēti saprotamos un prognozējamos darbības noteikumos un savu investīciju aizsardzībā no ar tirgu nesaistītiem faktoriem, piemēram, atsavināšanas, likuma varas (tiesiskuma) trūkuma, diskriminējošas attieksmes tirgū utt. Privātajiem ekonomiskajiem eiropeizācijas aǵentiem piemīt patiesa interese par mērķa valsts ekonomiskās un politiskas vides nostiprināšanu ilgtermina iesaistǐšanās vārdā un tāpēc, ka tās baidās no potenciālajiem finanšu zaudējumiem, šai videi degradējoties. To var uzskatīt par galveno atšksirību starp privātajiem politiskajiem eiropeizācijas aǵentiem, piemēram, nevalstiskajām organizācijām vai politiskajām partijām, un privātajiem ekonomiskajiem eiropeizācijas aǵentiem.

Spēja izvirzīt nosacījumus ir izškiroši svarīgs elements valstu, kas nav ES dalībvalstis, eiropeizācijā, bet šī spēja atšķiras privāto politisko aǵentu, piemēram, nevalstisko organizāciju un politisko partiju, un privāto ekonomisko aǵentu, piemēram, banku, pakalpojumu sniedzēju vai preču ražotāju, starpā. Tas ir, privātajiem politiskajiem aǵentiem ir nepieciešama aizmugure, savukārt privātie ekonomiskie aǵenti paši var nodrošināt savus ekonomiskos resursus un 
tādējādi ieviest nosacījumus izmaiņu īstenošanai. Pateicoties saviem resursiem, privātie ekonomiskie eiropeizācijas ağenti var darboties kā ietekmīgi eiropeizācijas veicinātāji. Kaut arī privātie ekonomiskie ağenti negarantē pašu dalību Eiropas Savienībā, tie var sniegt ārvalstu tiešās investīcijas. Šis faktors nereti ir kārdinošs valstīm, kurām nepieciešama ekonomikas kapitalizācija. Ticamība attiecībā uz solījumu izpildi un konkurētspējīgas atlīdzības sniegšanu par izmaiņu veikšanu ir centrālais aspekts, kas raksturo privāto eiropeizācijas aǵentu spēju projicēt kondicionalitāti eiropeizācijas mērķa valstīs.

Tika secināts, ka privātie dalībnieki pareizos apstākḷos un ar atbilstošām spējām ir piemēroti būt par nosacījumu noteicējiem un ES normu veicinātājiem. Tas ir ne tikai tāpēc, ka tieši tiktu prasītas iekšpolitiskas izmaiņas mērķa valstī, bet arī caur šo valstu nacionālo institūciju socializēšanu. Atkarībā no eiropeizācijas aǵenta veida, t. i., publiskā / privātā, ekonomiskā / politiskā, vietējā/ārzemju, arī aǵentu kapacitātes atšķiras. Publiskajiem aǵentiem, neatkarīgi no tā, vai tie ir politiski vai ekonomiski (piemēram, starptautiskās finanšu iestādes), teorētiski ir vislielākā kapacitāte, ņemot vērā to nosacījumu un mijiedarbību politiski un juridiski saistošu raksturu. Tādējādi akadēmiskajā literatūrā viṇi ir gandrīz tikai kā vien̄̄gie eiropeizācijas aǵenti.

Tajā pašā laikā attiecībā uz privātiem eiropeizācijas aǵentiem lielākās nosacījumu izvirzǐšanas spējas piemīt ekonomiskajiem aǵentiem, ņemot vērā to finanšu resursus. Privātie ārvalstu ekonomiskie eiropeizācijas aǵenti, piemēram, bankas, starptautiskie uzņēmumi vai pat individuālie uzṇēmēji, teorētiski var izmantot gan nosacījumu izvirzīšanas, gan socializācijas spējas. Sešu kritēriju kopums, kas tika izstrādāts šajā nodaḷā, definē saturu nosacījumu izvirzī̌sanas un socializācijas spējām, lai aktors būtu efektīvs eiropeizācijas aǵents (sk. 1.1. attēlu, Eiropeizācijas aǵentu kapacitātes). Proti, šī teorētiskā analīze veica arī pirmo soli, kas bija nepieciešama, lai pierādītu šīs disertācijas otro hipotēzi. Pēc tam, kad ir noskaidrots, ka privātie dalībnieki teorētiski var būt 
eiropeizācijas aǵenti, un tiem ir spējas par tādiem būt, šî disertācija turpināja šo konceptuālā model̦a piemērošanu, lai analizētu ārvalstu privāto ekonomisko aǵentu lomu - konkrēti ES izcelsmes banku lomu Latvijas eiropeizācijā.

Eiropeizācijas aǵentiem ir jāpiemīt divām spējām

\section{Nosacījumu izvirzǐšanas spēja}

1) skaidru nosacījumu klātbūtne

2) pēc nosacījumu izpildes piedāvāto labumu apmērs un nozīmīgums

3) draudu un solījumu uzticamība

3a) spēja saglabāt zemas iesaistes izmaksas

3b) gatavība nenodrošināt ar labumu, ja kritēriji netiek izpildīti

3c) spēja piedāvāt unikālu un augsti konkurētspējīgus labumus, lai izvairītos no paralēliem piedāvājumiem

3d) spēja notcikt, vai prasības tick izpildītas

4) spēja izaicināt un pārspēt iekšpolitiskos veto spēlētājus: ietekmīgas lobija grupas un politiskās institūcijas, kuras iestājas pret eiropeizāciju

\section{Socializēšanas spēja}

5) kontaktu intensitāte un aktīva socializēšana

5a) intensīvas sociālās mijeidarbības ar mērķa valsts lēmumu pieñēmējiem nodibināšana un specifiskas lomas ieņemšana

5b) aktīva pārliecināšanas un sabiedriskā atbalsta stratēgiju (piem., atalgošana, sodīšana un atbalstī̌sana) izmantošana attiecībā uz eiropeizācijas mērka valsti

6) sekošana sevis virzītajiem principiem un mentālā atbilstība

6a) sckošana augstākas kvalitātes principiem

6b) principi atbilst ieprickš izvcidotām vērtībām un izpratnēm mērķa valstīs

\section{1. attēls. Eiropeizācijas aǵentu kapacitātes}




\section{EIROPEIZĀCIJAS AĢENTU IZPĒTES METODES}

Sociologiskais institucionālisms un promocijas darbā izvēlētā teorētiskā pieeja ir sarežḡîti savā ontologiskajā pozīcijā, jo tiek atzīta gan racionālā (reālisma), gan konstruktīvistu (relatīvisma, sociālā) ontolog̣ija. Tas ir, socioloǵiskais institucionālisms un iepriekšējā nodą̧ā eiropeizācijas aǵenta noteikšanai izstrādātie kritēriji pieñem, ka lēmumu pieņemšanā pastāv gan racionālās izvēles teorijas elementi, gan attiecību sociālā konstruēšana, gan arī ideju loma. Būtiskā atšķirība ir tāda, ka socioloǵiskajā institucionālismā un šajā disertācijā tiek mēgeināts izskaidrot ideju pārmainīšanu, pamatojoties uz iesaistīto pušu interesēm un uzskatiem. Tādējādi šajā pētījumā tiek izmantotas divas argumentāciju kopas jeb loǵikas, ko izstrādājuši jaunā institucionālisma pārstāvji Džeimss Dž. Mārčs (James G. March) un Johans P. Olsens (Johan P. Olsen) un, proti, seku log̣ika un atbilstības loǵika. Pirmā ietver aktoru un aǵentu racionālā rīcībā balstîto interešu maksimālu īstenošanu, savukārt otrā uzsver uz noteikumiem un vērtībām balstītu uzvedību, ko ierobežo citu pušu piekrišana (March and Olsen, 1989, 1998a).

Lai iegūtu labāku skaidrojumu, šajā pētījumā tiek pielietota racionālās un sociālās ontoloǵijas kombinācija. Socioloǵiskajā institucionālismā un šajā disertācijā pielietotās kognitīvisma un racionālisma sintēzes kontekstā ir nepieciešams atzīt, ka normas un principi, kaut arī sociāli konstruēti un pārveidoti, no metodologisko mērķu viedokḷa pastāv kā novērojami fenomeni. Šai pamatotības teorijas (foundationalist) nostājai attiec̄̄gi ir nepieciešams piemērot epistemologiskā racionālisma pieeju, kas savukārt pētījumā ļauj veikt hipotēžu pārbaudi un cēlonssakarības noteikšanu. Turklāt sociologiskāā institucionālisma pārstāvju pētījumi tradicionāli analizē to, kā tiek strukturētas eiropeizācijā iesaistīto pušu savstarpējās attiecības, savukārt š̄ disertācija fokusējas tieši uz aǵentu aspektu viņu īstenotajā izpētē. 
Šajā promocijas darba nodạ̧ā tika definēti procesa izsekošanas metodoloǵiskie principi, pētot privātos eiropeizācijas aǵentus, kā arī identificēti galvenie datu avoti un datu apstrādes principi. Šī pētījuma pirmā apakšnodaḷa (Procesu izsekošanas metodoloǵija uz aǵentu-centrētā pētījumā) kalpoja, lai analizētu procesu izsekošanas metodoloǵiju. Savukārt otrajā apakšnodaļā (Dati Latvijas eiropeizācijas pētīšanai) aplūkotas pētniecības metodes, t.i., datu vākšana, datu avoti un datu apstrādes principi tālākai izpētei. Šajā nodaḷā izstrādātie procesu izsekošanas metodes principi un Latvijas pieredzes analīze š̄is disertācijas trešajā nodaḷā ḷāva pārbaudīit konceptuālo modeli.

Metodologiski pētījumā tika izmantota procesa izsekošanas metode, lai noteiktu cēlonssakarību starp privāto ārvalstu banku darbību un Latvijas eiropeizāciju. Procesu izsekošana ir svarīga metode kvalitatīvai pētniecībai un situācijas analīzei, kas l̦auj izdarīt cēloṇsakarības novērojumus un izšķirt neatkarīgos, atkarīgos un ietekmējošos (intervening) main̄̄gos. Procesu izsekošanas tehnika atbilda šīs disertācijas vajadzībām un mērķiem, jo l̦āva pārbaudīt teorētisko pamatu, konceptuālo modeli, kas tika izstrādāts iepriekšējā nodaḷā.

Procesu izsekošanas metodika l̦auj disertācijai izpētīt un secināt ne tikai par trešo hipotēzi - ka ES izcelsmes privātās ārvalstu bankas izmantoja savas nosacījumu izvirzī̌sanas un socializēšanas spējas eiropeizējot Latviju, bet arī izdarīt vispārīgus secinājumus par konceptuālā modeḷa pielietojamību eiropeizācijas privāto aǵentu izmeklēšanai. Proti, privātos ekonomiskos aktorus, piemēram, ārvalstu bankas, var uzskatīt par eiropeizācijas aǵentiem, ja procesa izsekošanas metode atklāj un apstiprina ietekmējošos mehānismus, t. i., sešus eiropeizācijas aǵentu kritērijus. Katrs no sešiem kritērijiem, kas izstrādāti iepriekšējā nodaļā, kalpoja par š̄ pētījuma cēloṇu mehānismiem (sk. 2.1. tabulu, Pētījuma shēma). 


\section{Pētījuma shēma}

\begin{tabular}{|c|c|c|}
\hline $\begin{array}{l}\text { Cēloniskais } \\
\text { stāvoklis (X) }\end{array}$ & \multicolumn{2}{|c|}{$\begin{array}{l}\text { ES izcelsmes ārvalstu privāto banku mijiedarbība ar Latviju tās } \\
\text { pievienošanās periodā ES no } 1995 \text {. līdz 2004. gadam }\end{array}$} \\
\hline \multirow{6}{*}{$\begin{array}{l}\text { Cēloniskais } \\
\text { mehānisms } \\
\text { (ietekmējošo } \\
\text { mehānismu } \\
\text { secība) }\end{array}$} & $\begin{array}{l}\text { Ietekmējošais } \\
\text { mehānisms } 1\end{array}$ & $\begin{array}{l}\text { Skaidri noteiktu apstākḷu klātbūtne ir redzama ES } \\
\text { izcelsmes privāto banku darbībā. }\end{array}$ \\
\hline & $\begin{array}{l}\text { Ietekmējošais } \\
\text { mehānisms } 2\end{array}$ & $\begin{array}{c}\text { Latvijas lēmumu pieņēmējiem ir svarīgi iegūt } \\
\text { apjomīgos un nozīmīgos labumus pēc nosacîjumu } \\
\text { izpildes. }\end{array}$ \\
\hline & $\begin{array}{l}\text { Ietekmējošais } \\
\text { mehānisms } 3\end{array}$ & $\begin{array}{l}\text { Banku draudu un solījumu ticamība ir klātesoša, } \\
\text { jo tās var saglabāt zemas kopējās iesaistīšanās } \\
\text { izmaksas; tās ir gatavas nesniegt labumu, ja } \\
\text { kritēriji nav izpildīti; tās piedāvā unikālus un l̦oti } \\
\text { konkurētspējīgus ieguvumus, lai izvairītos no } \\
\text { savstarpējas nosacītības; un tās spēj pārliecināties } \\
\text { par prasību izpildi. }\end{array}$ \\
\hline & $\begin{array}{l}\text { Ietekmējošais } \\
\text { mehānisms } 4\end{array}$ & $\begin{array}{c}\text { Spēja uzvarēt vietējos veto spēlētājus - ietekmīgu } \\
\text { lobistus un politiskās institūcijas, kas darbojas } \\
\text { pret Latvijas eiropeizāciju }\end{array}$ \\
\hline & $\begin{array}{l}\text { Ietekmējošais } \\
\text { mehānisms } 5\end{array}$ & $\begin{array}{l}\text { Kontaktu intensitāte un aktīiā socializācija ir } \\
\text { redzama, jo bankas ir izveidojušas intensīvu } \\
\text { sociālo mijiedarbību ar lēmumu pieņēmējiem } \\
\text { mērķa valstī un ieguvušas īpašu lomu, kāarī } \\
\text { aktīvi izmanto pārliecināšanas un sabiedriskā } \\
\text { atbalsta (social reinforcement) stratēǵijas, } \\
\text { piemēram, atalgojot, sodot un atbalstot Latvijas } \\
\text { lēmumu pieņēmējus. }\end{array}$ \\
\hline & $\begin{array}{l}\text { Ietekmējošais } \\
\text { mehānisms } 6\end{array}$ & $\begin{array}{l}\text { Ir novērojama sekošana ar saviem principiem un } \\
\text { mentālā atbilstība - bankas ievēroja augstākus } \\
\text { kvalitātes principus, ko pašas veicināja, kā arī to, } \\
\text { ka principi, ko tās veicināja, atbilda jau esošajām } \\
\text { vērtībām un izpratnei Latvijā. }\end{array}$ \\
\hline Iznākums (Y) & \multicolumn{2}{|c|}{ Ārvalstu privātās bankas ir eiropeizācijas ekonomiskie aǵenti. } \\
\hline
\end{tabular}

Promocijas darbā izmantotie informācijas avoti galvenokārt ir intervijas, bet arī dokumenti un sekundārā literatūra. Intervijas ar jautājumiem, kas balstās uz šiem kritērijiem, kḷuva par galveno datu avotu analīzei, jo izvēlētās bankas un to pārstāvji ir uzskatāmi par pārmaiṇu aǵentiem. Tika veiktas 25 intervijas ar "Hansabanka/Swedbank", "Unibanka/SEB", "Merita/Nordea", "Nord/LB" pārstāvjiem, kā arī Latvijas valsts pārvaldes institūciju un Latvijas Bankas 
pārstāvjiem, kuri visi periodā no 1995. gada līdz 2004. gadam bija attiecīgo institūciju amatpersonas, locekḷi valdēs vai nozīmīgi lēmumu pieṇēmēji. Intervijas palīdzēja gūt secinājumus un argumentus par to, kas motivēja un virza banku pašizpratni un attiecīgi to uzņēmējdarbības aktivitātes un principus. Intervēto valsts pārvaldes pārstāvju vidū ietilpst agrākie ārlietu ministri, finanšu ministri, ministru prezidenti, ministru prezidentu un prezidentu padomnieki, agrākās Finanšu ministrijas un Ārlietu ministrijas augsta līmeņa amatpersonas, kā arī agrākie īpašo uzdevumu ministri ar ES integrāciju saistītajos jautājumos, tiem pārstāvot dažādas politiskās partijas. Divās intervijās tika intervētas Latvijas Bankas augsta līmeņa amatpersonas un papildus tika veiktas četras konsultatīiās intervijas ar banku sektora ekspertiem. Intervijas ar amatpersonām un ministriem sniedza skaidrojumu par politiskās iesaistîšanās līmeni, ārvalstu kapitāla nozīmību, attiecīgo banku izvirzītajām prasībām, kā arī banku lomu Latvijas ES integrācijas procesā kopumā. Papildus tika veiktas arī 4 ekspertu intervijas.

Līdztekus pētīto banku gada pārskatiem, tika izmantoti arī Latvijas Bankas un Latvijas Republikas Finanšu ministrijas ziņojumi un statistika, kā arī Latvijas Finanšu un kapitāla tirgus komisijas sagatavotie ziņojumi; arhīvu dokumenti no Latvijas Republikas Finanšu ministrijas un Ārvalstu investoru padomes Latvijā, un Latvijas Bankas un Latvijas Finanšu un kapitāla tirgus komisijas ziņojumi, kā arī plašsaziņas līdzekḷlos (īpaši LETA arhīvos) pieejamie publiskie paziņojumi. Visbeidzot, tika izmantoti arī dati par ārvalstu banku tirgus dal̦ām, uzkrātajiem portfeļa ieguldījumiem pret IKP uz vienu iedzīvotāju, banku kapitalizāciju, izmaiņām akciju īpašumā un izsniegto kredītu apjomu. 


\section{PRIVĀTO ĀRVALSTU BANKU İSTENOTĀ LATVIJAS EIROPEIZĀCIJA}

Abās pirmajās nodaḷās tika izvirzīts un analizēts konceptuāls eiropeizācijas privāto aǵentu izpētes modelis, un noteikts, ka procesa izsekošanas metode ir labākā pieeja, lai pētìtu konkrēti Latvijas eiropeizāciju, ko veica privātie ekonomiskie eiropeizācijas aǵenti ES izcelsmes ārvalstu privāto banku veidolā. Šīs trešās, nodaļas mērķis bija sniegt papildu argumentus otrajai hipotēzei un pārbaudīt trešo hipotēzi. Šajā trešajā nodaļā tika secināts, vai Latvijas valsts ir pieņēmusi ES dalībvalstu privāto ārvalstu banku atbalstītos principus un politiku gan pragmatisko interešu dēḷ, gan tādēḷ, ka tām piemita Latvijas lēmumu pieņēmējiem līdzīga vispārējā kultūras un ideoloǵiskā pieeja. Nodạ̦ā arī tika secināts, vai un kāpēc ārvalstu banku kapitāls veicināja Latvijas dalību ES.

Šīs trešās nodaļas pirmajā apakšnodaḷā tika analizēta banku sektora un ārvalstu kapitāla strukturālā nozīme valsts ekonomikā, otrajā daļā tika sniegts skaidrojums par situāciju un attīstības procesiem, Latvijai virzoties uz ES, un Latvijas banku sektoru pirms pieteikuma iesniegšanas dalībai ES, savukārt trešajā daḷā tika analizēta attiecīgo ārvalstu banku loma Latvijā laikā no 1995. līdz 2004. gadam.

Tika secināts, ka Latvijas lēmumu pieņēmēji bija gatavi sadarboties ar ES izcelsmes ārvalstu bankām, un ka savstarpējai sadarbībai bija veicinoša ietekme uz Latvijas eiropeizāciju un vispārējo valsts integrāciju Eiropas Savienībā. Kāa tika apgalvots darba trešajā hipotēzē, privātās ārvalstu bankas izmantoja savas nosacījumu izvirzīšanas un socializēšanas spējas, lai padarītu Eiropeizētu Latviju. Detalizētāks trešās hipotēzes pierādījumu izklāsts ir pieejams šī kopsavilkuma sadaļā „Secinājumi”.

Tikmēr kopumā tika secināts, ka novērotajām bankām ne tikai bija skaidra izpratne par apstākḷiem, kas nepieciešami, lai ienāktu Latvijas tirgū, bet tās tos 
darīja zināmus arī Latvijas lēmumu pien̦ēmējiem un palīdzēja īstenot izmaiņas. Kapitāla pieplūdums no bankām Latvijai bija būtisks, jo tajā laikā nebija pieejami alternatīvi avoti līdzịgā apjomā ne vietējā, ne starptautiskā mērogā. Visbeidzot, novērotās bankas sadarbojās ar publiskajiem aǵentiem, tostarp Eiropas Komisiju, sekmējot Latvijas panākumus un pieņemot lēmumus par investīciju izvēršanu Latvijā. Latvijas lēmumu pien̦ēmēju attieksme bija vērsta uz iestāšanos Eiropas Savienībā un ES normu pieņemšanu, sevišķi attiecībā uz likuma varas (tiesiskuma) un labas pārvaldības principu stiprināšanu. Līdz ar to novēroto banku socializācijas process bija atbalstošs gan tehniskā, gan dažkārt publiskā līmen̄i.

Ir skaidrs, ka Latvijas lēmumu pieņēmēji un iegādāto banku darbinieki bija atvērti sadarbībai ar Zviedrijas, Somijas un Vācijas bankām, pamatojoties uz vispārējo mentālo atbilstību un atvērtību eiropeizācijas normām Latvijas sabiedrībā. Vienlaikus normu, vērtību un principu pieņemšana nebūtu bijusi iespējama bez aktīvas socializēšanas, politiskā atbalsta un politiskām vadlīnijām uzṇēmumiem, kas samazinājās pēc tam, kad Latvija kḷuva par konkurentu 2004. gada 1. maijā (Birkavs, 2017).

Tādējādi divdesmit gados, kad notikusi Ziemel̦valstu banku operāciju paplašināšana mazajā Baltijas valstī, ārvalstu banku sektora un valsts iekšējo lēmumu pieṇēmēju sadarbība ir piedzīvojusi gan kāpumus, gan kritumus. Šīs sadarbības pašos pirmajos gados Latvija ar entuziasmu sagaidīja kapitāla pieplūdumu, pārņēma acquis communautaire un mācījās no Ziemel̦valstu partneriem, vēlāk pēc pievienošanās ES izveidojās saspringta konkurence starp ārvalstu un vietējām bankām, savukārt vēlākās finanšu un ekonomikas krīzes periodā bija nepieciešama cieša savstarpējā sadarbība, lai saglabātu savstarpējo atkarību. 


\section{SECINĀJUMI}

Eiropeizācijas process ir atbildīgs par vienu no unikālākajām transformācijām cilvēces vēsturē. Process, kas ietver nacionālajai valstij un tās sabiedrībai relatīvi svešu normu un principu pārņemšanu kā priekšnoteikumu dalībai pārnacionālā organizācijā, ir pretrunā ar klasisko nacionālās valsts suverenitātes, neatkarības un autonomijas izpratni, kā arī klasiskā reālisma pieņēmumiem par starptautiskajām attiecībām. Tajā pat laikā eiropeizācijas procesā ir iesaistītas pragmatiskās intereses un aprēķini, ko veikuši gan attiecīgās ārējās prasības pieņemošās un ārējām saistībām piekrītošās valsts līderi un lēmumu pieñēmēji, gan eiropeizācijas aǵenti. Promocijas darbā veiktā analīze pamato, ka eiropeizācijas aǵenti ir ne tikai publiskie aktori, bet tie var būt arī privātie aktori. Tika konstatēts, ka privātie ekonomiskie eiropeizācijas aǵenti, kuru rīcībā ir finanšu resursi, var darboties kā ietekmīgi eiropeizācijas veicinātāji.

Šajā disertācijā, aplūkojot aǵentu aspektu eiropeizācijas procesā, kā arī privāto ekonomisko aktoru lomu un ietekmi eiropeizācijas procesā un Latvijas eiropeizācijā, tika savākti arī jauni empīriskie materiāli un iegūta jauna izpratne par Latvijas pievienošanos Eiropas Savienībai, kā arī par Latvijas finanšu un banku sektora attīstību. Visbeidzot šajā disertācijā tika definēts un testēts inovatīvs konceptuālais modelis, kas izmantojams turpmākā eiropeizācijas izpētē. Papildus šiem akadēmiskajiem ieguldījumiem šis pētījums ir l̦āvis palielināt vispārīgo izpratni par privāto banku interesēm un darbībām ārvalstīs, kā arī logiiku un argumentāciju, kas modernajā ekonomikā virza gan bankas, gan valstu valdības.

Eiropeizācijas jēedziens kombinācijā ar starptautiskās politiskās ekonomikas aspektiem no sociologiskā institucionālisma teorētiskās perspektīvas ir l̦āvis izanalizēt Latvijas Republikas eiropeizācijas procesa pieredzi periodā no 1995. līdz 2004. gadam un izvirzīt precīzus secinājumus par Latvijas teritorijā nepārtraukti funkcionējošo Zviedrijas, Vācijas un Somijas 
banku lomu. Latvijas vietējo banku pārņemšana un to operāciju paplašināšana tika īstenota, cieši sekojot attīstības procesiem valstī un tās cel̦am uz iestāšanos Eiropas Savienībā. Turklāt, kā norādīja intervētie politiķi, amatpersonas un attiecīgo banku pārstāvji, kā arī pārstāvji no banku sistēmas kopumā, pats Eiropas Komisijas lēmums atbalstīt Latvijas lūgumu par dalību ES bija cieši saistīts ar lobiju, ko jo īpaši īstenoja Zviedrijas publiskās institūcijas kopā ar Zviedrijas finanšu sistēmas pārstāvjiem. Pats Zviedrijas, Somijas un Vācijas uzñēmēju raidītais signāls par gatavību palielināt savu klātbūtni Baltijas valstīs un konkrēti Latvijā, bija spēcīgs arguments par labu Latvijas eiropeizācijas turpināšanai ilgtermiņā, jo bankas interesēja risku mazināšana jaunajā tirgū.

Privāto ekonomisko eiropeizācijas aǵentu galvenās intereses ietver ne tikai maksimālu pel̦nas palielināšanu, bet arī savu ilgtermiņa investīciju nodrošināšanu. Tas īpaši attiecas uz bankām, kas privātpersonām uz vairākām desmitgadēm izsniedz ilgtermiṇa aizdevumus, piemēram, hipotekāros kredītus. Pati acquis communautaire un tādu ES vērtību kā tiesiskuma ievērošana un laba pārvaldība pārņemšana kḷuva par svarīgiem veidojošajiem elementiem, lai Latvija transformētos par atbilstošu un daudzsološu ES dalībvalsti. Tādējādi bankas izmantoja savus ekonomiskos un politiskos resursus, lai panāktu izmaiņas uzņēmējdarbības kultūrā - pārn̦emot acquis, Latvijas uzņēmējdarbības vide tika padarīta līdzịgāka videi, kas pastāvēja jau esošajās ES dalībvalstīs. Tās bija gatavas nodrošināt, ka ne tikai to uzņēmējdarbība tiek īstenota prognozējamā, politiski un ekonomiski stabilā vidē, kurā to investīcijas un darbības aizsargā funkcionējoša juridiskā un tiesu sistēma, ko vada likuma vara, nevis korupcija un institūciju jeb autoritārā vara. Ārvalstu bankas ir ieinteresētas saglabāt finanšu sistēmas stabilitāti un sistēmas kvalitatīvo aktīvus, lai izvairītos no domino efekta, masveida finanšu līdzekḷu izṇemšanas no bankām un lieliem satricinājumiem. 
Visbeidzot legitīmas, labi veidotas un prestižas bankas ir ieinteresētas strādāt banku sistēmā, kurā nenotiek pretlikumīgas darbības un netiek veicināta noziedzīgi iegūtu līdzekḷu legalizēšana un izvairīšanās no nodokḷu maksāšanas. Visi šie principi savienojumā ar valsts vispārējās uzṇēmējdarbības kultūras un vides transformāciju ir svarīgi faktori no ilgtermiņa investoru skatupunkta. Moderno valstu, īpaši mazo, gadījumā ārvalstu tiešo investīciju piesaiste valsts ekonomikā ir izšķiroši svarīga. Promocijas darbā veiktā analīze liecina, ka eiropeizācija nav ideālistisks process. Tas ir pragmatisks process gan no mērķa valsts, gan aǵenta perspektīvas. Eiropeizācijas aǵentus virza to pragmatiskās intereses uzlabot vidi, pamatot savu politisko pozīciju un esību, kā arī nodrošināt sadarbību un ietekmi, darbojoties potenciālajās ES dalībvalstīs.

Ir jāpatur prātā, ka, lai aǵents spētu izvirzīt nosacījumus lēmumu pieṇēmējiem, tā rīcībā būtu jāatrodas ievērojamam vēlamā resursa vai atalgojuma apjomam. Kā aplūkots promocijas darba un š̄ kopsavilkuma trešajā nodạ̧ā, valsts un ekonomikas funkcionēšanai izšķiroši svarīgo resursu saraksta galvgalī atrodas finanšu resursi, tādēḷ bankas, kuru rīcībā ir spējas un zināšanas, lai organizētu un nodrošinātu kapitāla pieplūdi, ir būtiski procesa aǵenti. Tomēr, par spīti banku kapacitātei, tās nevar uzskatît par vienīgo eiropeizācijas veicēju. Turklāt to pienesumu Latvijas eiropeizācijā ir grūti izmērīt, jo bankas nedarbojās vienas pašas. Eiropeizācijas aǵenti reti darbojas vieni paši, jo procesā ir iesaistīti vairāki aǵenti. Šis aspekts sasaucas ar šī pētījuma centrālo pieṇēmumu, t.i., ka eiropeizācijas publiskie aǵenti nav vien̄̄gie, kas ir būtiski šajā procesā. Eiropeizācijas process zināmā mērā ir visaptverošs fenomens, kurā izmaiņas vienā sektorā ietekmē visas sistēmas, visas valsts funkcionēšanu. Attiecīgi prasības pieņemt noteiktus instrumentus vai likumdošanu vienmēr nozīmē politisku procesu, kas ietver dažādus aktorus, tostarp citas privātās ekonomiskās un politiskās struktūras. Tādējādi, kaut arī eiropeizācijas process ir ticis plaši pētīts, pamatojoties uz dažādām teorētiskajām un metodologiskajām pieejām, un 
ir kḷuvis par vienu no fundamentāliem jēdzieniem akadēmiskajā un profesionālajā literatūrā, tā kontekstā vēl joprojām ir pieejams būtisks potenciāls, ko turpmāk attīstìt.

Šis ved pie secinājuma, ka teorētiskās un empīriskās izpētes laikā apstiprinājās visas trīs hipotēzes. Pirmā hipotēze, ka privātie aktori var būt eiropeizācijas aǵenti, tika pierādīta pirmajā nodal̦ā, kurā tika konstatēts, ka par šo jautājumu trūkst akadēmiskās literatūras, bet nepastāv neviens teorētiskais arguments, kas neļautu uzskatît, ka privātie aktori spēj funkcionēt kāa eiropeizācijas aǵenti. Turklāt jauni akadēmiskie pētījumi par privāto eiropeizācijas aǵentu jautājumu ir vairāk nekā apsveicami un nepieciešami. Teorētiskā analīze parāda, ka socioloǵiskā institucionālisma pieeja l̦auj koncentrēties ne tikai uz strukturālo mijiedarbību, bet arī aǵenta aspektu. Aǵenta lomas uzsvēršana l̦auj efektīvi analizēt eiropeizācijas procesa gan kognitīvās, gan materiālās puses. Mūsdienu eiropeizācijas pētnieki apvieno aktoru racionālo motivāciju ar naratīviem un ideju sistēmu, kas l̦auj izskaidrot pārmaiṇas politiskajos procesos. Turklāt eiropeizācijas procesa teorētiskās definīcijas un vektori var viegli ietvert arī privāto aǵentu aspektu.

Eiropas integrācijas process ir sarežǵīta parādība, kas saista gan valsts, gan privātus dalībniekus, lai radītu pārmaiņas gan pašmājās, gan ārzemēs. Koordinācija un mijiedarbība, lai atvieglotu pārmaiņas, notiek ne tikai procesa izejas posmā, bet arī ievades posmā. Un šeit ir tas, kur debatēs un sarunās iesaistās privātie aǵenti, tostarp ekonomiskie. Privātie ekonomiskie aǵenti izplata savas intereses, tostarp normatīvās izpratnēs un vērtībās. Ieteikumi un prasības, ko viṇi publiski izpauž masu medijos vai institucionāli, tiešā sadarbībā ar amatpersonām, definēt to normatīvu pārmaiṇu politisko aǵentu raksturu. Tāpēc ir svarīgi, lai aǵents spētu veicināt pārmaiņas, nevis tas, vai aktors ir publisks vai privāts. 
Otrā hipotēze, ka aktoram, lai tas būtu efektīvs eiropeizācijas aǵents, ir jāpiemīt divām spējām: kondicionalitātes jeb nosacījumu izvirzīšanas spējai un socializēšanas spējai, tika apstiprināta divos soḷos. Pirmais solis bija teorētiskā izpēte. Socioloǵiskā institucionālisma pieeja un īpaši Franka Šimelfeniga darbs palīdzēja noteikt kritērijus, kas ir izšķiroši svarīgi, lai aktoru uzskatītu par eiropeizācijas aǵentu. Aktoram ir jāspēj radīt izmaiņas mērķa valstī. Un izmaiņas var radīt, ja politiskajai vai ekonomiskajai struktūrai ir nozīmīgi ekonomiskie vai politiskie resursi, kas to padara svarīgu eiropeizācijas mērķa valsts lēmumu pieņēmēju acīs. Taču spēja izvirzìt nosacījumus nav pietiekams izmaiṇu avots, ja nepastāv aktīva iesaistīšanās personiskā līmenī. Tādējādi spēja socializēt, būt klātesošam un uzklausītam arī ir l̦oti svarīga, lai aktors spētu funkcionēt un tiktu uztverts kā eiropeizācijas ag̊ents.

Abas spējas (nosacījumu izvirzīšanas un socializēšanas) teorētiskiem un izpētes mērķiem sadalīja sešos kritērijos (sk. 1.1. attēlu skaidrojumam). Tajā nosacījumu izvirzīšanā tikai izdalīti četri kritēriji: 1) skaidru nosacījumu klātbūtne; 2) pēc nosacījumu izpildes piedāvāto labumu apmērs un nozīmīgums; 3) draudu un solījumu uzticamība: 3a) spēja saglabāt zemas iesaistes izmaksas, 3b) gatavība nenodrošināt ar labumu, ja kritēriji netiek izpildīit, 3c) spēja piedāvāt unikālu un augsti konkurētspējīgus labumus, lai izvairītos no paralēliem piedāvājumiem, un 3d) spēja noteikt, vai prasības tiek izpildītas; 4) spēja izaicināt un pārspēt iekšpolitiskos veto spēlētājus: ietekmīgas lobija grupas un politiskās institūcijas, kuras iestājas pret eiropeizāciju.

Savukārt socializēšanas spēja sastāv no diviem kritērijiem. Pirmā (un piektā kopumā) ir 5) kontaktu intensitāte un aktīvā socializēšana, kas sastāv no diviem apakškritērijiem: 5a) intensīvas sociālās mijiedarbības ar mērķa valsts lēmumu pien̦ēmējiem nodibināšana un specifiskas lomas ieņemšana, un 5b) aktīva pārliecināšanas un sabiedriskā atbalsta stratēgiju (piem., atalgošana, sodīšana un atbalstī̌sana) izmantošana attiecībā uz eiropeizācijas mērķa valsti. 
Otrais (un sestais kopumā) ir 6) sekošana sevis virzịtajiem principiem un mentālā atbilstība, kas sastāv no diviem apakškritērijiem: 6a) sekošana augstākas kvalitātes principiem un 6b) principi atbilst iepriekš izveidotām vērtībām un izpratnēm mērķa valstīs.

Lai gan konceptuālais modelis šajā disertācijā tika pārbaudīts uz ārvalstu privātajiem ekonomikas pārstāvjiem, ir sagaidāms, ka tas būs piemērojams arī citiem eiropeizācijas aǵentiem, neatkar̄̄gi no tā, vai tie ir privāti vai publiski, politiski vai ekonomiski. Un ir skaidrs, ka privātie dalībnieki pareizajā situācijā un ar pietiekamiem resursiem ir spējīgi būt nosacījumu izvirzītāji un ES normu veicinātāji. Vislielākās nosacījumu izvirzī̌sanas iespējas ir ekonomiskajiem aǵentiem, ņemot vērā tiem pieejamos finanšu resursus. Pamatojoties uz šo log̣iku, šajā disertācijā tika analizēta ārvalstu privāto banku loma Latvijas iestāšanās ES laikā, pieņemot, ka ES izcelsmes ārvalstu bankas veicināja normatīvas izmaiņas Latvijā. Otrais solis, lai pierādītu otro hipotēzi, bija empīrisks pētījums, izmantojot procesa izsekošanas metodi, kā aprakstīts disertācijas un šī kopsavilkuma otrajā nodaḷā. Visi seši kritēriji un visi apakškritēriji skaidri iezīmējas, lai gan divu apakškritēriju izpilde bija nedaudz mazāk izteikta: „,5b) aktīva pārliecināšanas un sabiedriskā atbalsta stratēgeiju izmantošana attiecībā uz eiropeizācijas mērķa valsti”, un “6a) sekošana sevis virzītajiem principiem”. Līdz ar to var secināt, ka šajā pētījumā izstrādātais konceptuālais modelis izturēja pirmo empīisko testu.

Trešă hipotēze , ka ES izcelsmes privātās ārvalstu bankas izmantoja savas nosacījumu izvirzīšanas un socializēšanas spējas, lai eiropeizētu Latviju, tika apstiprināta, izmantojot procesa izsekošanas metodi disertācijas trešajā nodaļā. Visi seši teorētiskie kritēriji (ietekmējošie mehānismi), kas tika pārbaudīti attiecībā uz ES izcelsmes privāto ārvalstu banku īstenotās Latvijas eiropeizācijas piemēru, tika atzīti par klātesošiem. Secinājumi attiecībā uz trešo hipotēzi un šī 
pētījuma empīriskajiem pierādījumiem ir jāapkopo nedaudz detalizētāk. Vairāki no šiem secinājumiem kalpo arī kā praktiskas dabas rekomendācijas.

Pētījuma gaitā tika secināts, ka eiropeizācijas aǵenti skaidri pauda savu ieinteresētību Latvijas dalībā ES, kā arī banku sektora tiesiskā ietvara uzlabošanā, pretlikumīgo vai “aizdomīgo" uzn̦ēmējdarbības modelı mazināšanā. ES izcelsmes ārvalstu bankas kā priekšnosacījumu savai ienākšanai Latvijas tirgū izvirzīja banku sistēmu uzraugošo institūciju un š̄̃s sistēmas spēju pilnveidi, ES normu efektīvāku pārņemšanu ar finanšu institūcijām saistītajos sektoros un aktīvu likuma varas (tiesiskuma) un labas pārvaldības iedibināšanu. Prasību izpilde balstîjās uz Latvijas politiķu pragmatiskajiem aprēķiniem, ka ne tikai pati dalība ES, bet arī liela apjoma ārvalstu tiešo investīciju pieplūdums bija absolūti nepieciešams kā papildus mehānisms Latvijā īstenotajai finanšu sektora stabilizācijai pēc 1995. gada banku krīzes. Tā rezultātā Latvijas lēmumu pieņēmēji atradās spēcīgā pozīcijā un bija apņēmības pilni uzlabot tiesisko ietvaru, uzņēmējdarbības kultūru un vispārīgo sistēmu, lai pielāgotos lielo ārvalstu banku vajadzībām. Latvijas lēmumu pien̦ēmējiem bija politiskā griba pielāgoties nosacījumiem. Un ārvalstu bankas bija spējīgas raidīt nepārprotamus signālus izpildīt solījumus tikai gadījumā, ja Latvija īstenoja attiecīgās prasības. Skaidrā korelācija starp Latvijas iestāšanās sarunām, ES normu pārn̦emšanu un pētījumā ietverto Zviedrijas, Somijas un Vācijas banku aktivitāti kombinācijā ar l’oti zemajām tirgus analīzes izmaksām un ciešo sadarbību starp attiecīgajām nacionālajām publiskajām institūcijām un Eiropas Komisiju nolika bankas ideālā pozīcijā, lai tās spētu izpildīt savus solījumus nosacījumu izpildes gadījumā.

Vērā ņemamu alternatīvu nosacījumu izvirzišanas spēju trūkums no Krievijas un citu NVS valstu puses šo situāciju pastiprināja vēl vairāk. Vietējo konkurentu pārspēšana un veto spēlētāju izkonkurēšana bija viegli paveicama, jo valsts pārvaldes institūcijas attiecībā uz ES dalībvalstu banku ienākšanu Latvijā bija ļoti pozitīvi noskaņotas. Kapitāla, pieredzes un tehnologiju trūkums kopā ar 
lēmumu pien̦ēmēju vēlmi neitralizēt atsevišķu vietējo dalībnieku nevēlamo ietekmi radīja situāciju, kurā privātās ārvalstu bankas no Zviedrijas, Somijas un Vācijas spēja piedāvāt konkurētspējīgāku un kārdinošāku priekšlikumu, neskatoties uz prasībām un nosacījumiem, kuri tika izvirzīti kopā ar šo piedāvājumu. Tādējādi ir skaidri secināms, ka ES izcelsmes ārvalstu bankām kā privātajiem ekonomiskajiem eiropeizācijas aǵentiem bija vērā ņemama kondicionalitātes projicēšanas spēja. To rīcībā esošo finanšu un personāla resursu dēḷ bankas ir ietekmīgi aktori, kas veicināja veicināt vērtību, standartu un principu ieviešanu.

Līdzīga, bet grūtāk identificējama, ir privāto ekonomisko aktoru spēja socializēt. Šajā kontekstā būtu jāṇem vērā, ka uzņēmumi var sliekties ieņemt piesardzīgu attieksmi pret atklātu iesaistīšanos politiskajos jautājumos, ja vien tie nevēlas izdarīt tīšu spiedienu. Banku neiesaistī̌anās tiešajā lobijā vai pat interešu konfliktos savas darbības veikšanas laikā, veido daļu no labas pārvaldības un likuma varas principiem, kas savukārt veido daḷu no principiem, kas jāpārṇem, lai iestātos ES. Promocijas darbā veiktā analīze parādīja, ka ārvalstu privātajām bankām ir pietiekami liela socializēšanas spēja, kas tiek īstenota, izmantojot tiešo mijiedarbību, savu pozitīvo tēlu, tehniskos padomus, apmācības un zināšanas, ko tās sniedz gan valsts pārvaldes amatpersonām, gan vietējo pārṇemto banku darbiniekiem. Mijiedarbības un aktīvās socializēšanas intensitāte, pateicoties tuvajai saskarsmei ar lēmumu pieñēmējiem, tika galvenokārt uzturēta, sadarbojoties ar Latvijas Komercbanku asociāciju un Ārvalstu investoru padomi Latvijāa kā arī tieši mijiedarbojoties ar Finanšu ministrijas un Latvijas Bankas vidējā līmeņa amatpersonām. Turklāt bankas, pamatojoties uz savu pieredzi un zināšanām, ieguva arī noteiktu lomu acquis un banku sektora tiesiskā ietvara pārņemšanā.

Tāpat bankas, izmantojot institucionālos un personīgos kontaktus ar kolēgiem citās valstīs, aktīvi īstenoja "sabiedriskā atbalsta" stratēǵijas. 
Vienlaikus banku nostāja Latvijas publiskajā diskursā tika pausta reti, īpaši pirmajos gados pēc ienākšanas Latvijas tirgū. Š̉ zemā aktivitāte plašsaziņas līdzekḷıs ir skaidrojama ar nevēelěšanos zaudēt potenciālos klientus un partnerus, kritikai vai atbalstam kḷūstot pārlieku intensīvam. Savukārt no metodologiskāa ietvara aspekta 5a) apakškritērijs ir uzskatāms par klātesošu.

Visbeidzot sestais kritērijs jeb otrais kritērijs socializēšanas spējas kategorijā jeb "6) sekošana sevis virzītajiem principiem un mentālā atbilstība" arī bija novērojams ES izcelsmes banku rīcībā. Apakškritērija attiecināmība tomēr bija apstiprināma, kaut arī šī pētījuma ietvaros veiktajās intervijās tika pausta noteikta kritika un paškritika par to, vai pašas bankas vienmēr ievēroja savus sludinātos kvalitātes principus. Savas darbības laikā Latvijā bankas kopumā ievēroja likuma varas (tiesiskuma) principu un banku darbības standartus. Visbeidzot, principi, normas un standarti, ko pētījumā ietvertās bankas atbalstīja un veicināja, kopumā atbilda Latvijas lēmumu pieņēmēju, uzṇēmēju un sabiedrības jau esošajām vērtībām un principiem, tādēḷ viņu darbības noteica ne tikai tiesiskās, politiskās un ekonomiskās sistēmas rietumnieciskošanas un modernizēšanas vilinājums, bet arī demokrātiskās sistēmas, labas pārvaldības un darba ētikas principu atzīšana par saviem.

ES izcelsmes privātās ārvalstu bankas vēlējās eiropeizēt Latviju gan materiālo interešu dēl, gan arī tāpēc, ka nevēlējās kḷūt par daļu no banku sistēmas ar sliktu reputāciju un tēlu. No praktiskā viedokḷa raugoties, tirgi un vides, kurās darbojas bankas, var negatīvi ietekmēt to kredītreitingus un vispārējo kompānijas tēlu. Savukārt kredītreitingu pasliktināšanās nozīmē augstākas starpbanku kredītu cenas un intensīvāku uzraudzību no valsts pārvaldes iestāžu puses. Tādējādi ES izcelsmes bankas, īpaši no tādām valstīm kā Zviedrija, kurās banku darījumu nacionālie standarti ir pat augstāki nekā ES standarti, bija un joprojām ir ieinteresētas, lai Latvija rīkotos saskaņā ar likuma varu un labākajiem starptautiskajiem standartiem. Balstoties uz šo, būtu spekulatīvi prognozēt, vai 
konkrētās izpētē ietvertās bankas būtu ieinteresētas rīkoties pret Latvijas eiropeizāciju un Latvijas pievienošanos “četrām brīvībām”, jo šādas varbūtības pamatojumam trūkst empīrisko pierādījumu.

Cita spekulācija būtu analizēt, vai situācija un Latvijas eiropeizācijas ceľ̦̌ būtu citāds bez ES valstu privāto banku klātbūtnes. Šajā disertācijā tika izvirzīts apgalvojums, ka bankas nepārprotami veicināja eiropeizācijas procesu, bet ir nepieciešami tālāki pētījumi par citām ES valstīm un valstīm ārpus ES, lai konstatētu, vai ārvalstu kapitāls tajās ir spēēējis tādu pašu lomu. Viens no analīzei piemērotiem gadījumiem varētu būt Moldovas Republika vai atsevišksas Rietumbalkānu valstis.

Abas šīs spekulācijas meklē atbildes uz to, vai Latvijas eiropeizācijas process un rietumu kapitāla pieplūdums bija cieši saistīti procesi, kur abas puses - Latvijas lēmumu pieṇēmēji un novērotās ārvalstu bankas - bija ieinteresētas savstarpējā sadarbībā saskaņā ar „spēles noteikumiem”, ko norādīja un pieprasīja bankas. Nav skaidrs, vai ES bankas masveidā iesaistītos un ienāktu Latvijā un pārējās divās Baltijas valstīs, ja valstis nebūs ES dalībvalstis un tās neeiropeizētos. Taču pragmatiskā log̣ika liek domāt, ka tām būtu bijusi ierobežota klātbūtne, ierobežota izvēršanās tirgū un ierobežots skaits operāciju Latvijā, kā arī tās nebūtu kḷuvušas par strukturāli nozīmīgām bankām, ja valsts nebūtu pārņēmusi acquis communautaire. Visbeidzot, kā liecina ar̄̄ vairāki šajā disertācijā aplūkotās sekundārās literatūras piemēri, ārvalstu bankām ar ES izcelsmi bija tendence rīkoties ar tādu pašu stratēgiju kā citās Centrālās un Austrumeiropas valstīs un Dienvideiropas valstīs pirms to iestāšanās Savien̄ibā. Nav pamata uzskatīt, ka Baltijas valstis un konkrēti Latvija bija izṇēmums.

Lai šai situācijai rastu risinājumu, ir būtiski atcerēties, ka eiropeizācija ir aǵentu virzịts process. Attiecīgi kondicionalitātes jeb nosacījumu izvirzīšanas iedarbīgums pēc iestāšanās ES ir ḷoti atkarīgs no eiropeizācijas aǵentu noteikumu izvirzī̌̌anas un socializēšanas spējām. Tas ir, izzūdot sākotnējām spējām, to vietā 
jānāk jaunām. Eiropas Komisijai ir divas galvenās ietekmes spējas: Eiropas Savienības budžeta līdzekḷu sadalīšana un sankciju ieviešana. Eiropas Komisija valstis un uzṇēmumus var iesūdzēt Eiropas Tiesā un sodīt par atbilstîbas nenodrošināšanu. Tā kā valstis pēc iestāšanās ES saņem no tās finansējumu, kas var būt l̦oti svarīgs to ekonomiskajam sniegumam, tās parasti nav ieinteresētas riskēt. Savukārt no socializēšanas spējas viedokḷa publiskie eiropeizācijas aǵenti ir vairāk iesaistīti, pateicoties ES līmeņa lēmumu pieņemšanas procesam un ES pastāvošajam sadarbības tīklam. Taču abos gadījumos vienbalsības princips lēmumu pieņemšanā sliecas šīs spējas mazināt, jo dalībvalstīm ir iedarbīgs pretošanās resurss.

Tāpēc ir jāpatur prātā, ka ne tikai publiskie eiropeizācijas aǵenti, bet arī privātie ekonomiskie aǵenti turpina būt ietekmīgi arī pēc valsts pievienošanās Eiropas Savien̄̄bai. Privātie ekonomiskie eiropeizācijas aǵenti var joprojām izvirzīt nosacījumus, ja to rīcībā ir resursi un ekonomiskās ietekmes spēja. Un kā šis promocijas darbs demonstrē investīciju logiikas un pel̦nas gūšanas vēlmes dēḷ, privātie ekonomiskie eiropeizācijas aǵenti var pat pakāpeniski palielināt savu klātbūtni un ietekmi gadu gaitā. Atrašanās liela investora un valsts ekonomikai vitālu resursu turētāja pozīcijā l̦auj aktoriem saglabāt savu lomu kā izmaiṇu un eiropeizācijas aǵentiem. Konkrētajā gadījumā, bankas kā strukturālie ekonomiskie aktori ar ilgtermiņa investīcijām un riskiem sliecas iestāties par prognozējamu, godīgu un pat prestižu vidi, kurā strādāt. Vienlaikus šo mērķi nevajadzētu pārvērtēt, jo privātie ekonomiskie aǵenti primāri sliecas rīkoties atbilstoši biznesa log̣ikai. Politiskās logiikas ievērošana ir cieši saistīta ar uzṇēmējdarbības interesēm. Visbeidzot privāto aǵentu nosacījumu izvirzīšanas spējas nevajag arī pārvērtēt, jo to rīcība var tikt iegrožota ar nacionālās vai starptautiskās likumdošanas palīdzību.

Visi aspekti, kas šajā disertācijā ir apskatīti saistībā ar bankām, ir būtiski arī citu ārvalstu uzñēmumu un vietējo uzņēmēju kontekstā. Tie meklē politisko 
stabilitāti, tiesisko un fiskālo piesardzību, un kā lielie investori varētu potenciāli rīkoties kā eiropeizācijas aǵenti. Teorētiskā līmenī racionālās intereses uzlabot situāciju valstī, kurā tās darbojas vai ir gatavas darboties, un tīšā vai netǐšā socializācija, ko tās veic, mijiedarbojoties ar lēmumu pieņēmējiem, l̦autu deduktīvi secināt, ka arī lauksaimnieku organizācijas, rūpnieki, arodbiedrības un citi ietekmīgi ekonomiskie aktori varētu funkcionēt kā eiropeizācijas aǵenti. Vienlaikus tas ir turpmāko pētījumu uzdevums pievērsties, pirmkārt, jautājumam, vai citas uzņēmējdarbības struktūras Latvijas vai jebkuras citas eiropeizācijas procesā esošas valsts gadījumā atbilst eiropeizācijas aǵenta kritērijiem, un, otrkārt, jautājumam, vai šie aktori ir rīkojušies un vai rīkojas kā eiropeizācijas aǵenti. Tādējādi š̄ pētījuma mērḳiem izveidotais teorētiskais modelis varētu būt turpmāk piemērojams un pārbaudīts uz citiem potenciālajiem ekonomiskajiem vai politiskajiem eiropeizācijas ağentiem.

Tādējādi, būtu jāmin vēl daži uz turpmāko akadēmisko izpēti attiecināmi aspekti par konceptuālo ietvaru, kas tika izveidots š̄ pētījuma mērķiem. Var droši teikt, ka kritērijus var izmantot, un tie ir jāturpina pārbaudīt ne tikai attiecībā uz ārvalstu aǵentiem, bet arī vietējiem aǵentiem. Turpmākie pētījumi var būt gan par eiropeizāciju vispārīgi, gan par konkrētu vērtību veicināšanu, piem., tikai labas pārvaldības vai likuma varas (tiesiskuma) principu sekmēšanu. Šo veicināšanu var veikt gan valsts, gan privātie aktori dažādos pasaules reǵionos, piem. Austrumu partnerības vai Vidusāzijas valstīs. Īpašos gadījumos, ārvalstu privātie aǵenti, īpaši ekonomiskie, var pat uzturēt eiropeizācijas procesu, kad oficiāla sadarbība ar valsts aǵentiem ir problemātiska. Konceptuālo modeli varētu izmantot, lai izskaidrotu eiropeizācijas panākumus vai neveiksmi šajos reǵionos vai esošajās vai potenciālajās kandidātvalstīs.

Turklāt, veicot atbilstošus pielāgojumus, šo konceptuālo ietvaru varētu izmantot arī, lai skaidrotu tematiskos un aktuālos jautājumus, piemēram, valstu pozīciju saistībā ar Ekonomisko un monetāro savienību un Eiropas Savienības 
nākotni kopumā. No akadēmiskā skatupunkta šis ietvars ḷauj pilnveidot resursu jeb finanšu diplomātijas analīzes aspektu diplomātijas pētniecībā, īpaši kā daļu no ekonomiskās diplomātijas. Nav apšaubāms, ka visaptveroša salīdzinošā dažādu ārvalstu finanšu institūciju ietekmes, dažādu ātrumu, kādā katra valsts atveras ārvalstu finanšu investoriem, un attiecīgo korelāciju ar eiropeizācijas procesiem analīze paver iespējas dziḷākai tā izpratnei.

Visbeidzot, š̀i disertācija sniedz gan praktiskus, gan akadēmiskus ieguvumus, aplūkojot Latvijas pieredzi. Un tas padara to tikpat aktuālu, kā tas bija pirms 15 gadiem. Tajā secināts, ka eiropeizācijas aǵenti ir dažādi un ka nevienu spēcīgu dalībnieku nevajadzētu aizmirst vai nenovērtēt. Bet tās potenciāls un faktiskā aǵentūra ir jāanalizē un jāpārbauda. Vienkāršākā izvēle turpmākai konceptuālā model̦a piemērošanai būtu tajās valstīs, kuras pašlaik vēlas pievienoties Eiropas Savienībai. Valstis, kas atrodas eiropeizācijas procesā, var mācīties no Latvijas pieredzes un no aspektiem, kuri tostarp ir atklāti šajā promocijas darbā. Eiropas paplašināšanās process un Eiropas vērtību, normu un principu izplatī̌sana citos pasaules reǵionos joprojām ir būtiska ES darbības sastāvdaļa. No praktiskā ieteikuma viedokḷa esošās un potenciālās ES dalībvalstis var uzzināt, cik svarīgi ir socializēties un atzīt eiropeizācijas normas par standartiem un principiem, un par dal̦u no modernizācijas un dzīves līmeņa uzlabošanas. Valsts iestādes var izmantot ietekmīgus ārvalstu dalībniekus, lai uzvarētu vietējos veto spēlētājus. Tikmēr ārvalstu ekonomikas aǵenti var izmantot savu finansiālo kapacitāti, lai uzlabotu juridisko, kultūras un uzņēmējdarbības vidi, kurā viṇi vēlas darboties, ierosinot un veicinot konkrētus vispārpieņemtus uzlabojumus un izmaiņas. No akadēmiskā viedokḷa š̄ disertācijas konceptuālais modelis ir jāpiemēro pētījumos par kandidātvalstīm un potenciālajām kandidātvalstīm, kā arī aǵentiem, kas šajās valstīs ir veikušas taustāmas pārmaiņas. Tāpat kā pats Eiropas eiropeizācijas process, arī šis konceptuālais modelis paver jaunas iespējas un telpu attīstībai. 


\section{PUBLIKĀCIJU SARAKSTS}

Disertācijas rezultāti ir publicēti šādos akadēmiskajos izdevumos:

1. Bukovskis, K. 2018. Ziemel̦valstu privāto banku ietekme uz Latvijas iestāšanās Eiropas Savien̄īā procesu no 1995. līdz 2004. gadam. Zinātniskie raksti: 2017. gada sociālo zinātņu nozares pētnieciskā darba publikācijas. Politika un tiesības. Rīga: Rīgas Stradiña universitāte, 53-60.

2. Bukovskis, K. 2017. Privātie aǵenti eiropeizācijas procesā. Zinātniskie raksti: 2016. gada sociālo zinātņu nozares pētnieciskā darba publikācijas: Politika. Rīga: Rīgas Stradiṇa universitāte, 45-56. 


\section{BIBLIOGRĀFIJA}

Šajā sarakstā ir iekḷauti tikai būtiskākie avoti, kas minēti promocijas darbā un šajā kopsavilkumā. Lūdzu, skatiet pilno bibliogrāfijas sarakstu promocijas darba bibliogrāfijas sadaḷā.

1. Ådahl, M. 2002. Banking in the Baltics - The Development of the Banking Systems of Estonia, Latvia and Lithuania since Independence. The Internationalization of Baltic Banking (1998-2002). In: Focus on Transition. Available from: https://www.oenb.at/dam/jcr:17d369d9-7a89-4e85-8a7ed61b1e4a09c8/ftr_20022_tcm14-1693.pdf [viewed 11.09.2018.].

2. Akule, D. 2007. The Europeanization of Latvia: Becoming good Europeans? Providus. Available from: http://providus.lv/article_files/1286/original/Akule_v1.pdf?1328603457

[viewed 11.09.2018.].

3. Baltic Export. 2012. Nepilnu 20 gadu jauna nozare. No: Baltic Export. Iegūts no: $\mathrm{http}: / /$ balticexport.com/?article=nepilnu-20-gadu-jauna-nozare\&lang $=\mathrm{lv}$ 11.09.2018.].

4. Barisitz, S. 2002. The Emergence of Market-Oriented Banking Systems in Estonia, Latvia and Lithuania (1988-1997). Focus on Transition. 2, 84-106.

5. Birkavs, V. 10.10.2017. Author's personal interview in Riga.

6. Börzel, T. A. 1999. Towards Convergence in Europe? Institutional adaptation to Europeanization in Germany and Spain. Journal of Common Market Studies. 37(4), 576577.

7. Börzel, T. A. 2003. How the European Union Interacts with its Member States. HIS Political Science Series. Vienna: Institute for Advanced Studies, 93. Available from: http://aei.pitt.edu/1049/1/pw_93.pdf [viewed 11.09.2018.].

8. Börzel, T. A. 2011. When Europe Hits ... Beyond Its Borders: Europeanization and the Near Abroad. Comparative European Politics. 9(4-5), 394-413.

9. Börzel, T. A. and Panke, D. 2013. Europeanization. In: European Union Politics. 4th ed. M. Cini and N.P.S. Borragan, eds. Oxford: Oxford University Press, 115-125.

10. Börzel, T. A. and Risse, T. 2000. When Europe Hits Home: Europeanization and Domestic Change. European Integration Online Papers. 4(15). Available from: http://eiop.or.at/eiop/texte/2000-015a.htm [viewed 11.09.2018.].

11. Börzel, T. A. and Risse, T. 2003. Conceptualizing the Domestic Impact of Europe. In: The Politics of Europeanization. K. Featherstone and C. M. Radaelli, eds. Oxford: Oxford University Press, 57-80.

12. Börzel, T. A. and Risse, T. 2009. Conceptualizing the Domestic Impact of Europe. Domestic Politics and Norm Diffusion in International Relations: Ideas do not Float 
Freely. ResearchGate. Available from: doi:10.1093/0199252092.003.0003 [viewed 11.09.2018.].

13. Broadman, H. G. 2005. From Disintegration to Reintegration: Eastern Europe and the Former Soviet Union in International Trade. Washington: The World Bank.

14. Checkel, J. T. 1999. Social Construction and Integration. Journal of European Public Policy. 6(4), 545-560.

15. Checkel, J. T. 2001. Why Comply? Social Learning and European Identity Change. International Organization. 55(3), 553-588.

16. Checkel, J. T. 2005. International Institutions and Socialization in Europe: Introduction and Framework. International Organization. 59(04), 801-826.

17. Cowles, M. G., Caporaso, J. and Risse, T. 2001. Europeanization and Domestic Change: Introduction. In: Transforming Europe: Europeanization and Domestic Change. M. G. Cowles, J. Caporaso and T. Risse, eds. Ithaca: Cornell University Press, 1-20.

18. Dovladbekova, I., Eteris, E. and Zelmenis, D. 2008. Eiropas Savienības ekonomiskā politika un Latvija. Rīga: Rīgas Stradiṇa Universitāte.

19. Elsuwege, P. V. 2008. From Soviet Republics to EU Member States: A Legal and Political Assessment of the Baltic States' Accession to the EU. Leiden: Brill.

20. Epstein, R. 2008. The Social Context in Conditionality: Internationalizing Finance in Postcommunist Europe. Journal of European Public Policy. 15(6), 880-898.

21. Grabbe, H. 2001. How Does Europeanization Affect CEE Governance? Conditionality, Diffusion and Diversity. Journal of European Public Policy. 8(6), 1013-1031.

22. Grabbe, H. 2003. Europeanization Goes East: Power and Uncertainty in the EU Accession Process. In: The Politics of Europeanization. K. Featherstone and C. M. Radaelli, eds. Oxford: Oxford University Press, 303-330.

23. Grabbe, H. 2005. The EU's Transformative Power: Europeanization through Conditionality in Central and Eastern Europe. Basingstoke: Palgrave Macmillan.

24. Jacobsson, B. 2010a. Europeanization and Organization Theory. In: The European Union and the Baltic States. Changing Forms of Governance. B. Jacobsson, ed. New York: Routledge, 21-37.

25. Kelley, J. G. 2006. Ethnic Politics in Europe: The Power of Norms and Incentives. Princeton: Princeton University Press.

26. Knill, C. 2001. The Europeanisation of National Administrations: Patterns of Institutional Change and Persistence. Cambridge: Cambridge University Press.

27. Knill, C. and Lehmkuhl, D. 1999. How Europe Matters. Different Mechanisms of Europeanization. European Integration Online Papers. 3(7). Available from: http://dx.doi.org/10.2139/ssrn.302746 [viewed 11.09.2018.].

28. Kolodko, G. W. 2000. Globalization and Catching-Up: From Recession to Growth in Transition Economies. Washington: International Monetary Fund. 
29. Kostadinova, P. 2007. Europeanization of Economic Policy in the New Member States. In: European Union Studies Association Tenth Biennial International Conference (17 May 2007). Montreal. Available from: http://aei.pitt.edu/7942/1/kostadinova-p-05d.pdf [viewed 11.09.2018.].

30. Krūmiņš, G. 2017. Laika posma raksturojums (1990-2004). No: Latvijas tautsaimniecības vēsture. G. Krūmiņš, red. Rīga: Jumava, 359-373.

31. Ladrech, R. 1994. Europeanization of Domestic Politics and Institutions: The Case of France. Journal of Common Market Studies. 32(1), 69-88.

32. Ladrech, R. 2009. Europeanization and Political Parties. Living Reviews in European Governance. 4(1). Available from: http://europeangovernancelivingreviews.org/Articles/lreg-2009-1 [viewed 11.09.2018.].

33. Ladrech, R. 2010. Europeanization and National Politics. Basingstoke: Palgrave Macmillan.

34. March, J. G. and Olsen, J. P. 1989. Rediscovering Institutions. New York: Free Press.

35. March, J. G. and Olsen, J. P. 1998a. The Institutional Dynamics of International Political Orders. International Organization. 52, 943-969.

36. Ozolina, Ž. un Tisenkopfs, T. 2005. Eiropeizācijas sociālie un politiskie procesi mūsdienu Latvijā. No: Latvija eiropeizācijas krustceļos. Ž. Ozoliņa un T. Tisenkopfs, red. Rīga: LU Akadēmiskais apgāds, 8-22.

37. Pelz, M. E. 2016. Europeanization, National Party Systems and Lesbian, Gay, Bisexual and Transgender Rights: The Cases of Estonia, Latvia, and Lithuania: Doctoral Thesis: specialization-political science. Toronto.

38. Pettai, V. 2003. Introduction: Historic and Historical Aspects of Baltic Accession to the European Union. In: The Road to the European Union. Vol. 2: Estonia, Latvia and Lithuania. V. Pettai and J. Zielonka, eds. Manchester: Manchester University Press.

39. Quinn, D. P. and Inclan, C. 1997. The Origins of Financial Openness: A Study of Current and Capital Account Liberalization. American Journal of Political Science. 41(3), 771813.

40. Risse, T. 2009. Social Constructivism and European Integration. In: European Integration Theory. 2nd ed. A. Wiener and T. Diez, eds. Oxford: Oxford University Press, 144-160.

41. Schimmelfennig, F. 2000. International Socialization in the New Europe: Rational Action in and Institutional Environment. European Journal of International Relations. 6(1), 109-139.

42. Schimmelfennig, F. 26.04.2018. Author's personal interview in Brussels.

43. Schimmelfennig, F. and Sedelmeier, U. 2004. Governance by Conditionality: EU Rule Transfer to the Candidate Countries of Central and Eastern Europe. Journal of European Public Policy. 11(4), 661-679. 
44. Schimmelfennig, F. and Sedelmeier, U. 2005a. The Politics of EU Enlargement: Theoretical and Comparative Perspectives. In: The Politics of European Union Enlargement. Theoretical Approaches. F. Schimmelfennig and U. Sedelmeier, eds. London, New York: Routledge, 1-30.

45. Schimmelfennig, F., Engert, S. and Knobel, H. 2006. International Socialization in Europe: European Organizations, Political Conditionality and Democratic Change. New York: Palgrave Macmillan.

46. Spurga, S. 2007. Europeanization of Civil Society in the Baltic States: Promotion or Constraint of Democratization? Viešoji politika ir administravimas. 22, 57-67.

47. Strange, S. 1996. The Retreat of the State: The Diffusion of Power in the World Economy. Cambridge, Cambridge University Press.

48. Strange, S. 1998a. States and Markets. London: Bloomsbury Academic.

49. Strange, S. 1998b. Mad Money: When Markets Outgrow Governments. Ann Arbor: University of Michigan Press.

50. Svendsen, M. 2004. Gatavojoties kopdzīvei ar Eiropu: Latvijas izpildvaras eiropeizācija. Providus. Iegūts no: http://providus.lv/article/gatavojoties-kopdzivei-ar-eiropu-latvijasizpildvaras-eiropeizacija [sk. 11.09.2018.].

51. Swedbank. 2011. Swedbank's Annual Report 2010. In: Annual Reports. Available from: http://www.swedbank.org/investor-relations/financial-information-andpublications/annual-reports/CID_208131 [viewed 11.09.2018.].

52. Timofejevs Henriksson, P. 2014. Europeanization of Foreign-Aid Policy in Central and East Europe: The Role of EU, External Incentives and Identification in Foreign-Aid Policy Adoption in Latvia and Slovenia 1998-2010. Journal of European Integration. 37(4), 433-449.

53. Tõnismann, T. and Muizniece, L. 2016. Different Paths of Europeanization: The Case of Estonian and Latvian Research Policy. In: The sixth ECPR Graduate Student Conference at the University of Tartu (10 July 2016). Tartu: University of Tartu.

54. Tugdar, E. 2014. Europeanization of Minority Protection Policies in Latvia: EU Conditionality and the Impact of Domestic Factors on the Rights of Ethnic Russians. In: SSRN's eLibrary. Available from: http://dx.doi.org/10.2139/ssrn.2378561 [viewed 11.09.2018.].

55. Veebel, V. 2012. The EU Enlargement Conditionality. Goals, Efficiency, Shortcomings and Trends. Tallinn: European Studies Institute, Alfapress.

56. Vīksniņš, J. 2000. Introduction: Past Realities and Future Visions. In: Latvia entering the XXIst Century. Economics. Integration. Finance. I. Šteinbuka and J. Vīksniņš, eds. Riga: Nacionalais Medicinas apgads, 11-18.

57. Walecki, M. 2007. The Europeanization of Political Parties. Influencing the Regulations on Political Finance. In: EUI Working Papers. 29. Available from: 
http://cadmus.eui.eu/bitstream/handle/1814/7363/MWP-2007-29.pdf?sequence=1 [viewed 11.09.2018.].

58. Warleigh, A. 2001. Europeanizing Civil Society: NGOs as Agents of Political Socialization. Journal of Common Market Studies. 39(4), 619-639.

59. Zürn, M. and Checkel, J. T. 2005. Getting Socialized to Build Bridges: Constructivism and Rationalism, Europe and the Nation-State. International Organization. 59, 10451079. 